\title{
Application of multiple behaviour change models to identify determinants of farmers' biosecurity attitudes and behaviours
}

Richens, $\mathrm{IF}^{\mathrm{a}}{ }^{1}$, Houdmont, $\mathrm{J}^{\mathrm{b}}$, Wapenaar, $\mathrm{W}^{\mathrm{a}}$, Shortall, $\mathrm{O}^{\mathrm{c}}$, Kaler, $\mathrm{J}^{\mathrm{a}}, \mathrm{O}^{\prime}$ Connor, $\mathrm{H}^{\mathrm{d}}$ and Brennan, $\mathrm{ML}^{\mathrm{a}^{*}}$ ${ }^{a}$ School of Veterinary Medicine and Science, The University of Nottingham, Sutton Bonington Campus, Leicestershire, LE12 5RD, UK

${ }^{\mathrm{b}}$ Division of Psychiatry and Applied Psychology, School of Medicine, The University of Nottingham, Jubilee Campus, Wollaton Road, Nottinghamshire, NG8 1BB, UK

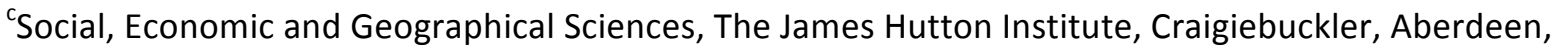
AB15 8QH, Scotland, UK

${ }^{d}$ Oxford Clinical Trials Research Unit (OCTRU), Centre for Statistics in Medicine, NDORMS, Botnar Research Centre, University of Oxford, Windmill Road, Oxford, OX2 6LD, UK

*Corresponding author: marnie.brennan@nottingham.ac.uk

\section{Abstract}

It has been recognised that few cattle farmers undertake biosecurity practices on their farms. Approaches that take into consideration individuals' preparedness for change, alongside beliefs thought to motivate the enactment of certain behaviours, may provide a framework for actuating tangible change. The aim of this study was to use a combination of behaviour change models to link beliefs with behaviour and identify possible key interventions to improve the uptake of biosecurity measures by dairy cattle farmers in Great Britain (GB). This is the first study to explore farmers'

\footnotetext{
${ }^{1}$ Present address: Centre for Applied Anatomy, University of Bristol, Southwell Street, Bristol, BS2 8EJ, UK
} 
practices and attitudes in relation to the prevention of direct (animal to animal contact); indirect (via fomites); and other biosecurity measures using a multi-theory approach.

A cross-sectional study was carried out, with postal questionnaires sent to 2505 dairy cattle farmers. Questions were asked about the extent to which a host of biosecurity measures were used, the influence of various stakeholders (e.g. veterinarians, industry bodies) in informing biosecurity choices, and the perceived control farmers felt they had over biosecurity on their farms. Farmer attitudes towards biosecurity were also explored. Two behaviour change models, the Transtheoretical Model, and the Theory of Planned Behaviour, were utilised. A variety of analysis methods were used to interrogate the data, including multivariable logistic regression.

A total of $908 / 2505$ (36.2\%) farmers responded, with 757 responses (30.2\%) deemed eligible for inclusion. Farmers generally fell into one of two categories: those that reported not applying biosecurity measures with no intention of doing so in the future, and those that reported undertaking biosecurity measures for some time. Farmers felt that biosecurity improved cattle health and welfare, but also felt that disease was inevitable. More farmers agreed with statements relating to their ability to control, rather than prevent disease. Analysis suggested a difference between influencing beliefs and whether specific types of measure were more likely to be undertaken. For example, farmers' beliefs about other stakeholders appeared to play a role in influencing the utilisation of measures preventing direct contact (e.g. nose to nose contact), rather than indirect contact (e.g. fomite transmission).

The use of a combination of behaviour change models has identified key variables to use for interventional approaches targeted towards the different type of biosecurity measure (preventing direct or indirect transmission) to improve the uptake of biosecurity on dairy cattle farms in GB. Other industry stakeholders should be aware of these variables when working with farmers to achieve optimal cattle herd health. 
Keywords: behaviour change model, transtheoretical model, theory of planned behaviour, attitudes, behaviour, biosecurity, disease prevention, disease control, questionnaire, survey, farmer, cattle

\section{Introduction}

Using disease prevention strategies (biosecurity) to maintain good animal health and welfare on cattle farms is crucial. Whether disease prevention strategies are employed by farmers depends on a number of factors, including receiving tailored advice from vets (Cardwell et al., 2016) and farmers' personal views on the procedures. It appears farmers perceive the implementation of biosecurity measures as beneficial (Sayers et al., 2013). However, such measures do not appear to be widely implemented, even in countries perceived to have 'biosecurity cultures' such as Sweden (Frössling and Nöremark, 2016) and Australia (Lanyon et al., 2015). Studies attempting to understand why this is the case have been outlined in recent comprehensive reviews, with a range of influences on farmer adoption of practices recognised (Mankad, 2016, Ritter et al., 2017).

Often these investigations focus on specific measures or diseases such as bovine tuberculosis (bTB), zoonotic diseases, bovine viral diarrhoea or Johne's disease (Ellis-Iversen et al. 2010, Ritter et al., 2016, O'Hagan et al., 2016; Broughton et al. 2016; Heffernan et al. 2016) and it is difficult to extrapolate such findings across general disease prevention strategies that address more than one disease (e.g. quarantining newly acquired animals once on a farm for a period of time combats a range of infectious diseases). If these practices are only applied in a disease specific way, there is a danger of farmers focusing on employing these measures in response to the threat of a single disease, and potentially not maintaining these when the threat for that pathogen is perceived to be lower. Additionally, the type of biosecurity measure undertaken in relation to whether it prevents disease transmission via direct (animal to animal contact) or indirect (via fomite) routes is likely to be 
important, but this is infrequently distinguished in studies looking at the uptake of biosecurity measures on farms.

It may be that farmers are unlikely to employ disease-specific preventive practices in isolation, as they may want to prevent a number of diseases across multiple species, or be prioritising other onfarm activities not necessarily animal health related over preventive measures (Scott, 2013). It is crucial to understand how farmers' attitudes towards disease prevention relate to their goals for the farm, as this could give an indication as to how willing farmers are to modify their activities. This includes identifying measures farmers perceive as useful but are not currently employing, and the factors that could potentially influence their uptake. This knowledge could usefully inform the targeting of interventions to promote the adoption of biosecurity measures.

One theoretical framework that can assist in identifying farmers' readiness to adopt biosecurity measures and provide guidance on appropriate interventions according to readiness is the Transtheoretical Model (TTM) of behaviour change (Prochaska and DiClemente, 1982). This model posits that behaviour change occurs through a series of five qualitatively different stages, from precontemplation (no intention to change) through to maintenance (the establishment of a behaviour for an extended period of time) (Figure 1).

\section{[Figure 1 here]}

Importantly, the theory proposes that the barriers to behaviour change are stage- and contextspecific, therefore suggesting that interventions will be most effective when they are tailored to an individual's current stage of change. The benefits of the TTM lies in its ability to explain why onesize-fits-all interventions targeted at large groups of people may not result in widespread behaviour change. The TTM has been employed in the medical field to identify readiness for change in relation to preventive behaviours such as occupational sun safety (Houdmont et al., 2015), and weight management (Alahuhta et al., 2011), with stage-matched interventions consistently showing 
stronger effects than generic ones (Evers et al., 2006, Craciun et al., 2012, Doda et al., 2015, GriffinBlake and DeJoy, 2006). To the authors' knowledge, it has not been applied in veterinary research.

To identify the stage- and context-specific factors that should be taken into account in the design of stage-matched interventions, it can be useful to supplement the TTM with a further model of behaviour change that is capable of identifying pertinent attitudes and behaviours typically held by individuals at each stage of change. One such model is the Theory of Planned Behaviour (TPB) (Ajzen, 1991). The central notion of the TPB is that attitudes and beliefs about a behaviour are linked to intention to perform the behaviour and, by extension, actual performance (Brennan et al., 2016). Consequently, interventions that seek to modify attitudes and beliefs held by those in the pre-action stages of change ought to result in movement through the stages towards a point at which the behaviours become embedded. The TPB model takes into consideration an individual's attitude toward the behaviour (behavioural beliefs), people that the individual are influenced by (normative beliefs) and what perceived behavioural control the individual feels they have over being able to undertake the behaviour (control beliefs) (Figure 2).

[Figure 2 here]

The TPB has been used previously across a variety of topics in medical research (Arden and Armitage, 2008, Choi et al., 2013), and in recent times has been used in veterinary research (Espetvedt et al., 2013, Bruijnis et al., 2013). The use of multitheories has been recommended to elicit the most appropriate solutions when tackling complex problems in human health (Eldredge et al. 2016). Given the many similarities between different human and animal health frameworks, is likely to result in more successful interventions in the animal health sector.

The aim of this study was to describe dairy farmer attitudes, beliefs, current behaviours and perceived openness to changing current activities related to different types of biosecurity practices using the Transtheoretical Model of behaviour change and the Theory of Planned Behaviour. 


\section{Materials and methods}

This study utilised a cross-sectional study design using postal questionnaires as a data collection method. It is reported using the STROBE-vet reporting guidelines (Sargeant et al., 2016).

\section{Sample design}

The target population of the survey was British dairy farmers. The sampling frame consisted of a database held by the dairy levy-board (AHDB Dairy). This database holds farm-level information about all levy-paying dairy farmers in Great Britain. A sample of farmers was selected using a stratified random sampling technique, proportionately representative of the density of farmers in each region of Great Britain, as present in the AHDB Dairy database (source for regions FSA via AHDB Dairy in November 2015). All farmers currently milking cattle were eligible for inclusion.

The required sample size was calculated using the total number of farmers held in the database at the time of the study $(n=10655), 5 \%$ margin of error, $95 \%$ confidence level and $50 \%$ response distribution (www.raosoft.com/samplesize.html). This resulted in a required sample size of 371. A $15 \%$ response rate was expected based on previous farmer questionnaire response rates, resulting in a total sample of 2480 questionnaires. Information from the holders of the database suggested there was a $1 \%$ rate of errors (e.g. invalid addresses) in the database. Therefore, a total of 2505 questionnaires were distributed.

\section{Questionnaire development}

The paper-based questionnaire was designed using Cardiff Teleform Version 10.5.1 (Verity Inc., Cambridge; a content capture system) and consisted of five sections over 15 pages. The introductory pages included information on the purpose of the survey, provided contact details of the researchers and the consent procedure (e.g. participation was voluntary), and informed 
participants that responses would be treated anonymously and confidentially. Part One contained demographic questions focused on eliciting the farmers age, level of education, herd size (number of adult milking cattle including dry cows), membership of assurance, health or disease schemes, type of production (conventional, organic, other) and how often the farm had received either preplanned or emergency visits from their private veterinarian in the past 3 months. This section also presented a definition of the meaning of the term 'biosecurity' in the context of the current study (defined as 'any measure used to control and/or prevent infectious disease spread onto, off or within a farm'). Part Two contained questions developed using the Transtheoretical Model (TTM) (Prochaska and DiClemente, 1982) to determine which biosecurity measures farmers used, and for how long they had been using them. This section consisted of Likert-type questions relating to 31 separate biosecurity measures with five single-choice tick boxes corresponding to the stages in the TTM: $1=1$ do not do this and have no plans to start doing so (pre-contemplation stage); $2=1$ do not do this but am thinking of doing so in the near future (contemplation stage); $3=$ I do not do this but am preparing to do so in the next month (preparation stage); $4=1$ do this and have done so for up to an including 6 months (action stage); $5=1$ do this and have done so for over 6 months (maintenance stage). Three of the measures included a sixth option (not applicable). Three free text boxes were provided at the end of the questions which had a modified TTM scale $(1=1$ do not do this but am thinking of doing so in the near future; $2=I$ do not do this but am preparing to do so in the next month; $3=1$ do this and have done so for up to an including 6 months; $4=1$ do this and have done so for over 6 months) for respondents to include any biosecurity measures they used, or were considering using, that they felt were not covered by any of the previous options. The biosecurity measures included in Part Two were informed by a number of sources, including previous research carried out by the research group (Hall and Wapenaar, 2012, Brennan and Christley, 2013, Brennan et al., 2016, Richens et al., 2015) and other literature. Parts Three and Four contained questions informed by the Theory of Planned Behaviour (TPB) (Ajzen, 1991) in order to identify factors that may influence farmers' biosecurity intentions and behaviours. Part Three included 16 statements 
relating to two dimensions of behavioural influence contained within the model, namely attitudes towards the behaviour (encompassing behavioural beliefs and outcome evaluations) and beliefs concerning ability to perform the behaviour (encompassing self-efficacy and controllability). Responses were given on a Likert-type scale with five single-choice tick boxes ( $1=$ strongly agree; $2=$ agree; $3=$ neither agree or disagree; $4=$ disagree; $5=$ strongly disagree). Part Four was similarly structured and included 19 statements relating to the normative belief dimension of the TPB that concerns the influence of the views of others on whether a behaviour is performed. This included the extent to which farmers agreed with statements focused on whether they felt pressure from a variety of different people/organisations (9 in total) to implement biosecurity, and how important farmers thought the opinion of the specific people/organisations were to them (the farmers). The statements included in Part Three and Four were derived from the analysis of semi-structured interviews (Brennan et al., 2016) and those appearing in other questionnaires utilising a TPB approach in relation to agriculture and disease control (Rehman et al., 2008, Nöremark et al., 2016). Part Five included a question allowing farmers to add any further comments; results from this section are not reported in this paper.

Pre-testing of the questionnaire was carried out with individuals in the Population Health and Welfare research group at the University of Nottingham. Corrections were made based on the pretesting, and a modified version was piloted with a convenience sample of 11 dairy farmers known to members of the research group. Further changes were subsequently made to improve the wording and reduce the overall number of questions.

The School of Veterinary Medicine and Sciences Ethics Committee at the University of Nottingham granted ethical approval for the study. 
The questionnaires were distributed via post during the third week of December 2015. A pen and pre-paid return envelope were included with each questionnaire. Unique identifiers were used on the questionnaire to allow for targeted reminders to be sent out to non-responders (Dilman et al., 2009). The first reminder (postcard) was sent to non-responders four weeks after the first mailing (January 2016). A second reminder (replacement questionnaire and pre-paid return envelope) was sent to the remaining non-responders four weeks following this (February 2016). No incentives were offered except for the pen in the original mail-out. A press release promoting the study was sent to the farming press (Farmer's Guardian, Farmer's Weekly) and other farming organisations (British Grassland Society).

Data handling and cleaning

All questionnaires that were returned to the researchers were checked to see if the respondent had indicated that they were no longer in dairy, not a dairy farm or did not want to participate.

Questionnaire data was considered eligible for inclusion in the analysis if the respondent at least included responses to the demographic information, and was in active dairy business. Eligible questionnaires were scanned using the Teleform software by a single researcher between January and April 2016. Questionnaires were scanned in batches, ranging between 1 and 8 questionnaires per batch. One form in every batch was reviewed in its entirety to ensure robust data entry. Free text box answers were typed manually. The scanned data were automatically exported into a Microsoft Office Access database (Microsoft 2013). Forms that could not be scanned were manually entered via the software.

The data was then exported into a Microsoft Office Excel document (Microsoft 2013) to allow for data cleaning and analysis (Van den Broeck et al., 2005). Each variable was checked for erroneous data. All blank entries from each question (except free-text boxes) were cross-referenced with notes made at the time of data entry to identify invalid responses versus no response. 


\section{Statistical analysis}

The results from the two behaviour change models were combined by using the TPB component results to explain the reported biosecurity activity results (TTM) specifically relating to those activities preventing direct contact (e.g. animal to animal transmission), preventing indirect contact (e.g. transmission via fomite such as equipment or vehicles) and preventing other types of contact.

Statistical analysis was performed using SPSS version 22 (IBM Corp.) and Microsoft Office Excel document (Microsoft 2013). All responses were explored using descriptive statistics (excluding free text answers). The measurement scale of those questions of a negative valance (e.g. 'Implementing biosecurity measures is costly' versus 'implementing biosecurity will improve the health of my cattle') were reversed to ensure all responses could be interpreted appropriately. Not all respondents answered all questions; denominators relating to the total number of people answering each question are reported in the results section where appropriate. Any information given by respondents within the free text boxes were categorised and arranged into groupings according to similar themes within statements by one of the authors (MB).

In order to assess the internal reliability of the questions in the three TPB components, a Cronbach's Alpha Coefficient was calculated for each TPB component [Behavioural beliefs (Attitude; A), Control beliefs (Perceived behavioural control; PCB) and Normative belief (Subjective norm; SN). An unstandardized alpha coefficient (Falk and Savalei, 2011) of 0.7 or above was considered to demonstrate adequate reliability (Nunnally and Bernstein, 1994). If reliability was adequate, a mean score was created representing each component for each respondent. Factor analysis was used to explore the construction of sub-components if a sufficient Cronbach's Alpha Coefficient was not achieved, utilising Principal Components and/or Principal Axis Factoring methods where appropriate (De Winter and Dodou, 2012). 
The biosecurity measures were assigned to one of three categories relating to the purpose of the measure - whether the measure aimed to prevent direct transmission of disease (e.g. avoiding cattle contact between neighbouring animals by secure boundary fencing), indirect transmission of disease (e.g. ensuring cleaning and disinfection of vehicles, equipment or personnel) or via other routes (e.g. vaccination). The preliminary analysis suggested that in relation to the TTM measures, responses were not normally distributed; respondents had generally nominated implementing the measure and had done so for over 6 months (category $=5$ ), or they had not implemented the measure and were not planning to do so (category $=1$ ). Responses were therefore dichotomised on the basis of TTM stages 1-3 versus stages 4-5. Next, to create a single outcome variable for each type of biosecurity measure (those preventing direct, indirect or other contacts), the mode of the items in each category was calculated. This resulted in each respondent having an overall score of 0 (not implemented) and 1 (implemented) for each of the three biosecurity measure categories (direct measures, indirect measures, other measures). The three binary logistic regression models were performed using a backwards likelihood ratio stepwise method (Dohoo et al. 2013). Prior to running the models, all explanatory variables were investigated for correlations using Kendall's tau for continuous variables, and cross tabulations (chi-square) for categorical variables (Field, 2011). Comparisons between continuous and categorical variables were carried out using a Mann-Whitney U test (Field, 2011).

Univariable regression was carried out initially; if the $p$-values for predictor variables were 0.25 or less, they were included in the final multivariate model (Du and Tan, 2015). This high alpha threshold served to ensure that no predictor variables that might make a meaningful contribution to explaining variance in the outcome variables were excluded from subsequent multivariate analyses. In the multivariable regression, model fit was explored using Hosmer and Lemeshow analysis (Field, 2011). The model's ability to distinguish between the binary outcomes compared to the baseline model was investigated using the chi-square Omnibus goodness of fit test along with the correct classification of cases, and the amount of variability explained by the model was measured using 
both Cox \& Snell and Nagelkerke R Square analysis. Alpha values of less than 0.05 were considered significant; using a Bonferroni correction (Petrie and Sabin, 2005) across all 3 models, a final significance value equal to 0.02 or less was considered statistically important. Multicollinearity (correlation between variables) in the final model was assessed by calculating the Tolerance Statistic, the Variance Inflation Factor (VIF) and examining the Eigen values (and Condition Indices) and Variance Proportions for influencing variables via linear regression (Midi et al., 2010). Variables were considered to be collinear if tolerance scores were more than 0.5 , VIF values were greater than 2, large Eigen values occurred relative to the others or Condition Indices were much greater than the others, or if Variance Proportions close to 1 appeared in a number of comparisons for the same variable.

\section{Results}

\section{Response rate and demographics of responders}

Questionnaires were posted to 2505 farmers and at the first reminder approximately 2200/2505 (87.8\%) postcards were sent to non-responders, with 1987/2505 (79.3\%) second reminders sent (replacement questionnaires). One hundred and twenty-nine (5.1\%) responders indicated that they were no longer milking, were going out of milk imminently or were not a dairy farm and $12(0.5 \%)$ indicated that they were not willing to participate. Notification was received from twenty two (0.9\%) responders for 'other' reasons, which included post being returned to sender and notification of the death of the individual. The final response rate for questionnaires eligible for inclusion in the database (i.e. were milking cattle, were happy to participate and had at least completed the demographic questions) was $30.2 \%(n=757 / 2505)$.

The mean age of the respondents was 52 (range 17-85, n=743). The median herd size was 145 (range 7-1750, IQR 83-207; $n=743$ ). In relation to type of dairy herd, $94.4 \%$ of respondents ( $n=710 / 752$ ) 
described their herd as conventional, $4.7 \%$ as organic $(n=35 / 752)$ and $0.9 \%$ as in an organic conversion period, or other type of system $(n=7 / 752)$. When asked if the farm was involved in any assurance, health or disease schemes, $97.8 \%(n=730 / 746)$ of respondents indicated that their farm was involved in a scheme, $2.0 \%(n=15 / 746)$ were not, and $0.1 \%(1 / 746)$ did not know if they were in a scheme or not. Approximately $81.3 \%$ indicated that they had completed their secondary school level education ( $n=613 / 754$ ) and $69.1 \%$ indicated they had completed further qualifications or education $(n=511 / 739)$.

Respondents reported having a median of $4($ IQR $2-6 ; n=677)$ pre-planned veterinary visits (e.g. routine fertility visits, herd health visits), and a median of 1 (IQR $1-1 ; n=677)$ emergency or unplanned visits over the past 3 months. When asked whether the number of visits they had was representative of what they usually received on their farm, $84.8 \%(n=629 / 742)$ of respondents answering the question said it was typical, with $15.2 \%$ of respondents saying it was not typical $(n=113 / 742)$. Reasons given for why the number of visits were not typical for the farm were mostly centred around those herds who were block calving so specific times of the year were particularly busy ( $n=30 / 113)$, and bTB testing, either routine herd or pre-movement tests, or because of bTB breakdowns in neighbouring herds $(n=27 / 113)$.

\section{Biosecurity measures reported as carried out on farms}

Most farmers were fairly polarised in relation to the biosecurity measures they nominated they carried out, indicating that they were not doing a measure and had no plans to start, or carried out the measure and had done so for a period of time. In relation to the direct biosecurity measures, most farmers nominated that they were minimising contact with their neighbour's animals, quarantining sick animals and running closed herds (Figure 3). Conversely, many farmers nominated that they did not double fence around their farm, and did not quarantine, or carry out disease testing, on newly arrived animals. A direct measure that farmers were considering implementing in the future was disease testing of newly acquired animals (Figure 3). 
In relation to the indirect biosecurity measures, a large proportion (90.7-94.5\%) of farmers

nominated that they were undertaking regular vermin control, ensuring general farm cleanliness and hygiene, and avoiding spreading fields with important slurry and avoiding grazing pastures recently spread with slurry (71.3-71.6\%; Figure 4). A large proportion of farmers nominated that they did not house their cattle all year round, provide bins for dog faeces on footpaths through their farms, restrict the number of visitors to the farm or manage any footpaths through their farms (Figure 4). Indirect measures a number of farmers were considering implementing were ensuring visitors clean and disinfect after visits and also checking the cleanliness and disinfection of visitors' vehicles and equipment.

In relation to other biosecurity measures, a large proportion (65.1\%), but not all, farmers nominated reviewing their biosecurity with their vet annually. Additionally, more farmers nominated that they used vaccination to control the effects of a disease currently circulating on their farm (66.8\%) in comparison to using vaccination to prevent the occurrence of a disease not already present on the farm (45.2\%; Figure 5). Farmers nominated participating in a disease control and accreditation programme and breeding for disease resistance as other types of measure they were considering undertaking in the future.

\section{[Figure 3 here]}

\section{[Figure 4 here]}

\section{[Figure 5 here]}

\section{Belief-elicited responses nominated by farmers}

A large proportion of farmers $(62.3-65.8 \%)$ agreed with statements relating to biosecurity improving the productivity and health and welfare of their cattle, and that biosecurity measures were worth implementing (Figure 6). Many farmers agreed with statements relating to biosecurity measures being costly and time consuming to implement. 
A large percentage of farmers nominated that they thought infectious disease on a dairy farm was inevitable (47.5\%), and agreed with statements that it was easier to control disease on a farm (65.1\%) than prevent disease coming onto a farm (42.1\%; Figure 7). A two thirds majority (65.6\%) of farmers agreed that there was evidence that biosecurity measures were effective, but many were less confident about implementing a new biosecurity measure, with only $39.8 \%$ agreeing with statements that it would be easy. The majority of farmers (85\%) indicated they were confident they knew the current disease status of their herd.

Overall, most farmers were ambivalent towards (42.9\%) or disagreed (36.8\%) with a statement about feeling pressure from people around them to implement biosecurity measures, with around one fifth (20.4\%) agreeing with the statement. Farmers agreed or strongly agreed that they thought their milk buyer (72.2\%), DEFRA (69.9\%), AHDB Dairy (62.4\%) and their vet (57.7\%) thought it was important that they implemented biosecurity measures on their farm (Table 1). However, when farmers were asked about statements focused on how important the opinion of the various stakeholders were to them in relation to the implementation of biosecurity measures on their farms, they strongly agreed or agreed that their milk buyer $(83.2 \%)$, their vet $(82.1 \%)$ and DEFRA $(51.7 \%)$ were most important.

\section{[Figure 6 here]}

\section{[Figure 7 here]}

\section{[Table 1 here]}

Reliability assessment of TPB components

After appropriate inversions were carried out, adequate Cronbach's Alpha Coefficients were achieved for the behavioural $(0.80)$ and normative (0.92) belief component questions of the TPB. Therefore mean scores were used to represent the behavioural and normative components of the TPB. The Cronbach's Alpha Coefficient for the control belief component was not adequate (0.56). 
Low correlations between variables (less than 0.3 ) meant that subcomponents could not be constructed. Each question was therefore used as an individual component for further analyses.

\section{Logistic regression modelling}

Significant associations occurred between a number of explanatory variables, such as production type (conventional versus organic), completion of secondary school, and completion of higher level education, versus a number of other variables, and were therefore excluded prior to univariable regression (14 variables in total taken forward).

\section{Univariable logistic regression}

For the model focusing on measures preventing direct, indirect and other contacts, 9,10 and 9 variables, respectively, were considered eligible to be taken forward to the multivariable regression models (for further detail see Appendices 3-6).

\section{Multivariable logistic regression}

Multicollinearity (correlation between variables) was not apparent between variables in the final models. In all three models, farmers appeared to be more likely to be carrying out biosecurity measures if they felt that there was a point to implementing biosecurity measures on their farm (control belief). In both the direct and other contact models, farmers appeared to be more likely to be carrying out direct biosecurity measures if they were influenced by the opinion of, or believed that their subjective norms (normative beliefs, e.g. vets) thought it was important that they implemented biosecurity measures on their farm, and they knew the current disease status of their herd (control belief).

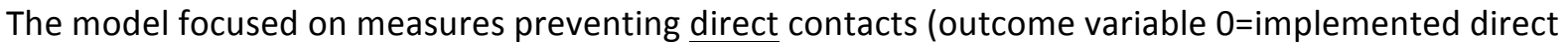
measures and 1=did not implement direct measures) found evidence of a difference between the 2 
binary outcomes $\left(X^{2}=59.30, p<0.0001\right)$ and correctly classified $64 \%$ of cases. In addition to the results above, the older the farmer, the more likely it appeared that direct biosecurity measures were being carried out (Table 2). The more emergency veterinary visits the farm had, the less likely it appeared that measures were being carried out. The Hosmer and Lemeshow analysis demonstrated adequate model fit.

\section{[Table 2 here]}

The model focused on measures preventing indirect contacts (outcome variable $0=$ implemented indirect measures and 1=did not implement indirect measures) found evidence of a difference between the 2 binary outcomes $\left(X^{2}=71.68, p<0.0001\right)$ and correctly classified $64 \%$ of cases. In contrast to the direct contact model, farmers appeared to be more likely to carry out indirect biosecurity measures if they believed that infectious disease on a dairy farm was not inevitable (control belief; Table 3). Additionally, they were more likely to carry out indirect biosecurity measures if they had more positive attitudes (behavioural beliefs) towards the benefits of using indirect biosecurity measures (e.g. that it made a difference for their cattle and farm). The Hosmer and Lemeshow analysis demonstrated adequate model fit.

\section{[Table 3 here]}

The model focused on the use of other biosecurity measures (outcome variable $0=i m p l e m e n t e d$ other measures and 1=did not implement other measures) found evidence of a difference between the 2 different binary outcomes $\left(X^{2}=76.50, p<0.0001\right)$ and correctly classified $66 \%$ of cases. Farmers that had more preplanned veterinary visits in the past 3 months appeared to be more likely to undertake other types of biosecurity measure (Table 4). Hosmer and Lemeshow analysis demonstrated adequate model fit.

\section{[Table 4 here]}




\section{Discussion}

This study shows that attitudes and factors intrinsic to the farmer, such as whether farmers felt there was a point to implementing biosecurity measures on their farm, appear to affect how likely farmers are to undertake biosecurity measures related to the prevention of specific disease transmission routes (direct, indirect or other types of contact). This is the first time that biosecurity practices have been explored by focusing on prevention of direct versus indirect contacts, and other types of measures. The modelling results show that there were differences between these categories of biosecurity measures. This can be taken to mean that exploring different categories within biosecurity has analytic merit and breaks down the term 'biosecurity' into more theoretically useful subcategories which has not previously been explored. The use of multitheories here enabled these measure specific findings to be discovered, and therefore can assist individuals communicating with and encouraging farmers to undertake biosecurity measures on their farms to target their interventions more specifically and successfully.

The polarisation of farmers into those doing biosecurity (for some time previously) and those not doing biosecurity (and not considering starting) could be indicative of the somewhat cautious attitudes held by many farmers in the industry in the UK (AHDB, 2016). This made it necessary to dichotomise stage of change responses into pre-action and action categories rather than using the five stages on a continuum. This has implications for the use of this model for the staging of farmers in relation to preventive medicine, but also potentially for other topics. Further exploration of this approach with other topics is required to draw definitive conclusions. It also highlighted the practices most likely to be considered for change, including disease testing and accreditation programmes. This knowledge provides support for recent initiatives such as the BVD Free campaign (www.bvdfree.com) and schemes like CHeCS (Cattle Health Certification Standards; www.checs.co.uk), and presents an opportunity to develop stage-matched interventions that might help to transition individuals from the pre-action to action stages (Hammer et al., 2015). With this 
knowledge, change may be more likely with the appropriate advice and assistance from vets and other herd health providers as these measures are already being contemplated. It has been previously identified in farmers managing udder health that change is more likely to occur when it is more aligned with what is already intrinsically perceived as important or likely by the farmer (Jansen and Lam, 2012). It is also noteworthy that farmers perceive veterinarians as lower down the list of stakeholders that think they (farmers) should be undertaking biosecurity. This suggests that although there is a clear desire from farmers to speak with their vets about biosecurity, the perception about vets is that they are less likely to be concerned about whether farmers undertake biosecurity. The reason for this finding is unknown, and could be related to veterinary surgeons not actively bringing up the topic of biosecurity with farmers, farmers not actively engaging their vet in discussions on biosecurity, or potentially ineffectual farmer-vet communication (Ruston et al., 2016). Future work should focus on the communication strategies used by farmers and veterinary surgeons when discussing disease prevention, and explore further the role of the milk buyer in encouraging farmer biosecurity.

It appears from the investigations around attitudes and beliefs that many farmers reportedly see the benefits of using biosecurity, so a lack of education around awareness of biosecurity is unlikely to be the reason behind lack of implementation as previously reported by veterinarians (Pritchard et al., 2015). However the idea of disease being 'inevitable' on farms suggests that farmers do not necessarily perceive that preventing disease is within their control, which is echoed in other studies (Shortall et al., 2016). This aligns with more farmers reporting a greater agreement with statements relating to being able to control disease compared with preventing disease from entering their farms. This is a fundamental conceptual issue when identifying barriers to the use of biosecurity measures on farms and is at odds with the desired move within the veterinary profession to move to a 'predict and prevent' rather than 'test and treat' approach (Orpin and Sibley, 2014). It could also be a reflection of how farmers conceptualise disease. Additionally, farmers are reportedly confident that they have a good understanding of the disease status of their farm. However, if disease is 
considered inevitable by farmers, this could highlight a lack of understanding of what diseases or sub-clinical diseases could be a problem in their herds, particularly if testing is not carried out. This signposts again to the need to establish good communication channels between farmers, vets and other herd health advisors.

If factors that motivate intention to adopt biosecurity measures are known, stakeholders are in a position to develop interventions that are more likely to succeed. If those interventions are tailored to the stage of change a farmer is currently within, the TPB and TTM models can work synergistically. Control beliefs appear to be important across all 3 types of biosecurity practice, with normative beliefs purportedly more important for the implementation of measures preventing direct, and other types of disease transmission routes, on dairy farms. The importance of subjective norms (which include veterinarians) in the direct and other models aligns with the finding regarding the number of veterinary visits (preplanned and emergency) recorded in the past 3 months, but could also be indicative of other management effects not captured here. In a recent study, different stakeholders became more important when looking at different control measures for bTB (Maye et al., 2017), so this indicates even within control measures for the same disease, influential stakeholders on farmers can differ. The industry partners considered important to farmers in relation to biosecurity, such as veterinarians, milk buyers and DEFRA, could utilise this information to their advantage. For example, if advisors are recommending that farmers focus on the quarantine of newly arrived stock, identifying and engaging with stakeholders (e.g. vet, milk buyer) who the farmer perceives as important may help the likelihood of uptake. In contrast, behavioural beliefs, or those relating to attitudes, appear to be more important in determining the likelihood of farmers undertaking measures preventing indirect disease transmission routes. For example, if the recommendation is that the focus should be on preventing transmission via equipment use, identifying how farmer attitudes relate to this are likely to help translation into practice. This finding corroborates with research conducted by Nöremark et al. (2016) using the TPB to investigate the use of protective clothing on farms in Sweden in that behavioural beliefs (attitudes) were more highly 
associated with intention. This is the first time that this difference in beliefs across the different types of biosecurity measure has been identified. This could be utilised by other sectors of the farming industry when promoting the virtues of the different measures to farmers, particularly if they have been identified as important and pertinent things to change on an individual farm. Farm and farmer factors appears to be most significant in relation to the undertaking of direct measures to prevent disease transmission, with older farmers more likely to implement these types of measure. The finding relating to age agrees with results from an Irish study (Sayers et al., 2013) but is different to results from other studies (Shortall et al., 2017, Nöremark et al., 2016). The Swedish study focused on investigating farmer attitudes from multiple types of production unit (cattle, pig, small ruminant and mixed farms) which could explain the difference. Other studies conducted with dairy cattle farmers on topics unrelated to biosecurity that used the TPB framework identified that normative beliefs (Jones et al., 2015) and behavioural beliefs (Lind et al., 2012) were more likely to predict behaviour. In a study conducted across a number of Scandinavian countries, behavioural beliefs were more likely to predict behaviour in Danish, Norwegian and Swedish farmers than in Finnish farmers, where control beliefs were more important (Espetvedt et al., 2013).

Important messages generated from the current study, particularly for milk buyers and the veterinary profession, are the acknowledgement of the importance of psychology and subsequent communication skills when conversing with farmers, both of which have been recognised previously in the veterinary literature (Christopher, 2010, Jansen and Lam, 2012, Pedersen, 2016). Research has highlighted that farmers are willing to discuss new topics when requested by their vet (Derks et al., 2013). The communication between farmers and veterinary surgeons is a key area affecting uptake of all types of biosecurity practice and the findings in the current study relating to uptake of indirect measures corresponding to more pre-planned visits from veterinary surgeons is likely to support this. Further investigation of this finding is required, but ultimately it is imperative that the messages being given and received around disease prevention and control are as they were 
intended. Further work is needed to investigate the implementation of the study findings to onfarm scenarios and to understand the magnitude of the effects of the influencing variables.

The age distribution of the farmers in the study was consistent with what has been found in other studies (Toma et al., 2015), although the number of farmers having completed secondary school and further qualifications is greater in the current study comparatively. No suggestions were made in the questionnaire as to what was meant by 'further qualifications', so it may be that those nominated by farmers do not necessarily represent University or agricultural college level training. The mean herd size of our respondents is comparable with the average number across the United Kingdom (AHDB Dairy Published June 2015) https://dairy.ahdb.org.uk/resources-library/marketinformation/farming-data/average-herd-size/\#.WYxiq-mQyM9. The proportion of farmers involved in assurance or other health schemes is similar to those reported by Jones et al. (2015). Therefore, the farmers in this study are likely to represent a substantial proportion of the dairy farmers in Great Britain.

Study limitations

The strengths of this study, its nationwide coverage and use of established theoretical frameworks, are acknowledged alongside some limitations. There appeared to be a lack of consistency across responses pertaining to control beliefs. This could reflect actual differences in farmer beliefs, or could have arisen from questionnaire design. Previous TPB studies and the construction of questions were used for guidance during the development of the questionnaire so it is perhaps less likely to be the latter. Farmer response bias (social desirability) (Kristensen and Jakobsen, 2011) may have influenced respondents when answering the questions. Additionally, those farmers with better biosecurity or more positive attitudes towards biosecurity may have been more likely to participate. However, additional analyses carried out (not reported here) indicate that there was a significant difference between those responding earlier and later to the questionnaire for some of the biosecurity variables measured (Bonsell 2017). This is likely to indicate that a range of farmers 
responded to the questionnaire and makes response bias less probable. For unknown reasons, there were also questions that fewer farmers completed, particularly three of the questions relating to the use of measures preventing against indirect contacts, which may have led to non-representative results. This poor response could be related to question placement in the questionnaire, or indicative of a lack of usage of these practices. Most importantly, farmer reported levels of biosecurity undertaken on farms could differ from what is actually carried out, which has been identified in other studies focused on biosecurity in pig production (Simon-Grifé et al., 2013).

Previous criticisms raised in relation to the TPB focus on the assumption that decision-making is a rational process, which it is not always the case (Ajzen, 1991) and assumes that the most important determinant of behaviour is intention (Webb and Sheeran, 2006). The creator of the model suggests that additional constructs could be added to enhance the predictability of the variance in intentions or behaviours (Ajzen, 1991) and is something for researchers to consider if using this theory in isolation. Disadvantages of the TTM that have been highlighted relate to the implied linear nature of the stages of change (when in reality it may not be) and presumes the forward transition through the stages is associated with an increasing strength of behavioural intention (Webb and Sheeran, 2006). Ultimately, the suitability of any model relates to the aim of what is trying to be achieved, and should be chosen accordingly (Eldredge et al., 2016). A multitheory approach was used to address both the motivation (TPB) and action (TTM) aspects of individual farmer behaviour change in this instance.

It has been reported previously that there are differences between what individuals understand by the term 'biosecurity' (Gilmour et al., 2011), which could have affected how individuals responded to the questions in the questionnaire. However, a definition was provided within the questionnaire so this is less likely to have affected individuals' interpretations of the questions. 


\section{Conclusion}

Individuals working with farmers towards collective herd health goals to improve disease prevention and control on dairy farms should be mindful of the different novel influencers identified here on the uptake of biosecurity practices relating to the prevention of disease transmission via direct, indirect and other measures.

Factors that advisors need to consider include whether a biosecurity practice is already prioritised by the farmer, their attitude toward disease prevention and how much implementation control they believe they have. Additionally, the role of the milk buyer and veterinary surgeon appears fundamental in the uptake of all types of biosecurity measure. Future work should test stagematched interventions to assist individuals in transitioning from the pre-action to action phases, and should investigate further the role of these stakeholders in such interventions.

\section{Acknowledgements}

Many thanks to the farmers who gave up their valuable time to contribute to this study. This work was supported by AHDB Dairy (www.dairy.ahdb.org.uk), a levy funded, not for profit organisation working on behalf of dairy farmers in Great Britain and a division of the Agriculture and Horticulture Development Board; the Centre for Evidence-based Veterinary Medicine and The University of Nottingham.

\section{Conflicts of interest}

The authors declare no conflict of interest. The funding sponsors had no role in the design of the study; in the collection, analysis, or interpretation of the data; in the writing of the manuscript, and in the decision to publish the results. 


\section{References}

AHDB. 2016. Levy payer satisfaction survey - key findings [Online]. https://ahdb.org.uk/. [Accessed 14th December 2017].

AJZEN, I. 1991. The theory of planned behavior. Organizational behavior and human decision processes, 50, 179-211.

ALAHUHTA, M. A., KORKIAKANGAS, E. E., KERÄNEN, A.-M., KYNGÄS, H. A. \& LAITINEN, J. H. 2011. Using pictures as vignettes to assess stages of change in weight management. Scandinavian Journal of Social Medicine, 39, 403-409.

ARDEN, M. A. \& ARMITAGE, C. J. 2008. Predicting and explaining transtheoretical model stage transitions in relation to condom-carrying behaviour. British Journal of Health Psychology, 13, 719-735.

BONSELL, C. E. 2017. Investigating farmers attitudes towards biosecurity and their effect on questionnaire response date. Undergraduate dissertation, University of Nottingham.

BRENNAN, M. L. \& CHRISTLEY, R. M. 2013. Cattle producers' perceptions of biosecurity. BMC Veterinary Research, 9, 71.

BRENNAN, M. L., WRIGHT, N., WAPENAAR, W., JARRATT, S., HOBSON-WEST, P., RICHENS, I. F., KALER, J., BUCHANAN, H., HUXLEY, J. N. \& O'CONNOR, H. M. 2016. Exploring attitudes and beliefs towards implementing cattle disease prevention and control measures: a qualitative study with dairy farmers in Great Britain. Animals, 6, 61.

BROUGHAN, J. M., MAYE, D., CARMODY, P., BRUNTON, L. A., ASHTON, A., WINT, W., ALEXANDER, N., NAYLOR, R., WARD, K., GOODCHILD, A. V. \& HINCHLIFFE, S. 2016. Farm characteristics and farmer perceptions associated with bovine tuberculosis incidents in areas of emerging endemic spread. Preventive Veterinary Medicine, 129, 88-98.

BRUIJNIS, M., HOGEVEEN, H., GARFORTH, C. \& STASSEN, E. 2013. Dairy farmers' attitudes and intentions towards improving dairy cow foot health. Livestock Science, 155, 103-113.

CARDWELL, J., VAN WINDEN, S., BEAUVAIS, W., MASTIN, A., DE GLANVILLE, W., HARDSTAFF, J., BOOTH, R., FISHWICK, J. \& PFEIFFER, D. 2016. Assessing the impact of tailored biosecurity advice on farmer behaviour and pathogen presence in beef herds in England and Wales. Preventive Veterinary Medicine, 135, 9-16.

CHOI, J. H., CHUNG, K. M. \& PARK, K. 2013. Psychosocial predictors of four health-promoting behaviors for cancer prevention using the stage of change of Transtheoretical Model. Psycho-Oncology, 22, 2253-2261.

CHRISTOPHER, P. 2010. Psychology of persuasion: evolving into advice-orientated consultants. Veterinary Times, 40, 6-8.

CRACIUN, C., SCHÜZ, N., LIPPKE, S. \& SCHWARZER, R. 2012. Enhancing planning strategies for sunscreen use at different stages of change. Health Education Research, 27, 857-867.

DE WINTER, J. C. \& DODOU, D. 2012. Factor recovery by principal axis factoring and maximum likelihood factor analysis as a function of factor pattern and sample size. Journal of Applied Statistics, 39, 695-710.

DERKS, M., VAN WERVEN, T., HOGEVEEN, H. \& KREMER, W. D. 2013. Veterinary herd health management programs on dairy farms in the Netherlands: use, execution, and relations to farmer characteristics. Journal of Dairy Science, 96, 1623-1637.

DILMAN, D., SMYTH, J. \& CHRISTIAN, L. 2009. Internet, mail, and mixed-mode surveys: The tailored design method. John Wiley \& Sons, New Jersey.

DODA, D., ROTHMORE, P., PISANIELLO, D., BRIGGS, N., STEWART, S., MAHMOOD, M. \& HILLER, J. E. 2015. Relative benefit of a stage of change approach for the prevention of musculoskeletal pain and discomfort: a cluster randomised trial. Occupational Environmental Medicine, oemed-2015-102916. 
DU, H. \& TAN, M.T. 2015. Describing data, modelling variation and statistical practice, in: Lu, Y., Fang, J., Tian, L., Jin, H. (Eds), Advanced medical statistics. World Scientific Publishing Co. Pty. Ltd., Singapore, pp.21-50.

ELDREDGE, L.K.B., MARKHAM, C.M., RUITER, R.A., KOK, G. and PARCEL, G.S. 2016. Planning health promotion programs: an intervention mapping approach. John Wiley \& Sons, San Francisco.

ELLIS-IVERSEN, J., COOK, A. J., WATSON, E., NIELEN, M., LARKIN, L., WOOLDRIDGE, M. \& HOGEVEEN, H. 2010. Perceptions, circumstances and motivators that influence implementation of zoonotic control programs on cattle farms. Preventive Veterinary Medicine, 93, 276-285.

ESPETVEDT, M. N., RINTAKOSKI, S., WOLFF, C., LIND, A.-K., LINDBERG, A. \& VIRTALA, A.-M. K. 2013. Nordic veterinarians' threshold for medical treatment of dairy cows, influence on disease recording and medicine use: mild clinical mastitis as an example. Preventive Veterinary Medicine, 112, 76-89.

EVERS, K. E., PROCHASKA, J. O., JOHNSON, J. L., MAURIELLO, L. M., PADULA, J. A. \& PROCHASKA, J. M. 2006. A randomized clinical trial of a population-and transtheoretical model-based stressmanagement intervention. Health Psychology, 25, 521.

FALK, C. F. \& SAVALEI, V. 2011. The relationship between unstandardized and standardized alpha, true reliability, and the underlying measurement model. Journal of Personality Assessment, 93, 445-453.

FIELD, A. 2011. Discovering statistics using SPSS, Sage publications, London.

FRÖSSLING, J. \& NÖREMARK, M. 2016. Differing perceptions-Swedish farmers' views of infectious disease control. Veterinary Medicine and Science, 2, 54-68.

GILMOUR, J., BEILIN, R. \& SYSAK, T. 2011. Biosecurity risk and peri-urban landholders-using a stakeholder consultative approach to build a risk communication strategy. Journal of Risk Research, 14, 281-295.

GRIFFIN-BLAKE, C. S. \& DEJOY, D. M. 2006. Evaluation of social-cognitive versus stage-matched, selfhelp physical activity interventions at the workplace. American Journal of Health Promotion, 20, 200-209.

HALL, J. \& WAPENAAR, W. 2012. Opinions and practices of veterinarians and dairy farmers towards herd health management in the UK. Veterinary Record, 170, 441-441.

HAMMER, S. S., LIEBHERR, M., KERSTEN, S. \& HAAS, C. T. 2015. Adherence to worksite health interventions: practical recommendations based on a theoretical framework. Journal of Workplace Behavioral Health, 30, 325-343.

HEFFERNAN, C., AZBEL-JACKSON, L., BROWNLIE, J. \& GUNN, G. 2016. Farmer attitudes and livestock disease: exploring citizenship behaviour and peer monitoring across two BVD control schemes in the UK. PloS One, 11, p.e0152295.

HOUDMONT, J., MADGWICK, P. \& RANDALL, R. 2015. Sun safety in construction: a UK intervention study. Occupational Medicine, 66, 20-26.

JANSEN, J. \& LAM, T. J. 2012. The role of communication in improving udder health. Veterinary Clinics: Food Animal Practice, 28, 363-379.

JONES, P., MARIER, E., TRANTER, R., WU, G., WATSON, E. \& TEALE, C. 2015. Factors affecting dairy farmers' attitudes towards antimicrobial medicine usage in cattle in England and Wales. Preventive Veterinary Medicine, 121, 30-40.

KRISTENSEN, E. \& JAKOBSEN, E. B. 2011. Danish dairy farmers' perception of biosecurity. Preventive Veterinary Medicine, 99, 122-129.

LANYON, S., ANDERSON, M. \& REICHEL, M. 2015. Survey of farmer knowledge and attitudes to endemic disease management in South Australia, with a focus on bovine viral diarrhoea (bovine pestivirus). Australian Veterinary Journal, 93, 157-163.

LIND, A.-K., THOMSEN, P. T., RINTAKOSKI, S., ESPETVEDT, M. N., WOLFF, C. \& HOUE, H. 2012. The association between farmers' participation in herd health programmes and their behaviour concerning treatment of mild clinical mastitis. Acta Veterinaria Scandinavica, 54, 1. 
MANKAD, A. 2016. Psychological influences on biosecurity control and farmer decision-making. A review. Agronomy for Sustainable Development, 36, 40.

MAYE, D., ENTICOTT, G. \& NAYLOR, R. 2017. Using scenario-based influence mapping to examine farmers' biosecurity behaviour. Land Use Policy, 66, 265-277.

MIDI, H., SARKAR, S. \& RANA, S. 2010. Collinearity diagnostics of binary logistic regression model. Journal of Interdisciplinary Mathematics, 13, 253-267.

NÖREMARK, M., LEWERIN, S. S., ERNHOLM, L. \& FRÖSSLING, J. 2016. Swedish Farmers' Opinions about Biosecurity and Their intention to Make Professionals Use clean Protective clothing When entering the stable. Frontiers in Veterinary Science, 3.

NUNNALLY, J. \& BERNSTEIN, I.H. 1994. Psychometric theory. McGraw Hill, New York.

O'HAGAN, M., MATTHEWS, D., LAIRD, C. \& MCDOWELL, S. 2016. Herd-level risk factors for bovine tuberculosis and adoption of related biosecurity measures in Northern Ireland: A casecontrol study. The Veterinary Journal, 213, 26-32.

ORPIN, P. \& SIBLEY, D. 2014. Predict and prevent versus test and treat. Veterinary Record, 174, 403405.

PEDERSEN, S. 2016. Building and assessing effective herd health planning. Veterinary Times, 46, 1014.

PETRIE, A. \& SABIN, C. 2005. Medical statistics at a glance, Blackwell Publishing, Oxford.

PRITCHARD, K., WAPENAAR, W. \& BRENNAN, M. L. 2015. Cattle veterinarians' awareness and understanding of biosecurity. Veterinary Record.

PROCHASKA, J. O. \& DICLEMENTE, C. C. 1982. Transtheoretical therapy: Toward a more integrative model of change. Psychotherapy: theory, research \& practice, 19, 276.

REHMAN, T., GARFORTH, C., MCKEMEY, K., YATES, C. \& RANA, R. 2008. Farmers' behavioural inclinations and their influence on the anticipated response to the reform of the Common Agricultural Policy in England. Journal of Farm Management, 13, 1-29.

RICHENS, I., HOBSON-WEST, P., BRENNAN, M. L., LOWTON, R., KALER, J. \& WAPENAAR, W. 2015. Farmers' perception of the role of veterinary surgeons in vaccination strategies on British dairy farms. Veterinary Record, 177, 465.

RITTER, C., JANSEN, J., ROCHE, S., KELTON, D. F., ADAMS, C. L., ORSEL, K., ERSKINE, R. J., BENEDICTUS, G., LAM, T. J. G. M. \& BARKEMA, H. W. 2017. Invited review:Determinants of farmers' adoption of management-based strategies for infectious disease prevention and control. Journal of Dairy Science, 100, 3329-3347.

RITTER, C., JANSEN, J., ROTH, K., KASTELIC, J., ADAMS, C. \& BARKEMA, H. 2016. Dairy farmers' perceptions toward the implementation of on-farm Johne's disease prevention and control strategies. Journal of Dairy Science, 99, 9114-9125.

RUSTON, A., SHORTALL, O., GREEN, M., BRENNAN, M., WAPENAAR, W. \& KALER, J. 2016. Challenges facing the farm animal veterinary profession in England: A qualitative study of veterinarians' perceptions and responses. Preventive Veterinary Medicine, 127, 84-93.

SARGEANT, J. M., O'CONNOR, A. M., DOHOO, I. R., ERB, H. N., CEVALLOS, M., EGGER, M., ERSB ØLL, A. K., MARTIN, S. W., NIELSEN, L. R., PEARL, D. L., PFEIFFER, D. U., SANCHEZ, J., TORRENCE, M. E., VIGRE, H., WALDNER, C. \& WARD, M. P. 2016. Methods and Processes of Developing the Strengthening the Reporting of Observational Studies in Epidemiology - Veterinary (STROBE-Vet) Statement. Zoonoses and Public Health, 63, 651-661.

SAYERS, R., SAYERS, G., MEE, J. F., GOOD, M., BERMINGHAM, M. L., GRANT, J. \& DILLON, P. 2013. Implementing biosecurity measures on dairy farms in Ireland. The Veterinary Journal, 197, 259-267.

SCOTT, P. R. 2013. The challenges to improve farm animal welfare in the United Kingdom by reducing disease incidence with greater veterinary involvement on farm. Animals, 3, 629646. 
SHORTALL, O., RUSTON, A., GREEN, M., BRENNAN, M., WAPENAAR, W. \& KALER, J. 2016. Broken biosecurity? Veterinarians' framing of biosecurity on dairy farms in England. Preventive Veterinary Medicine, 132, 20-31.

SHORTALL, O., SUTHERLAND, L. A., RUSTON, A. \& KALER, J. 2017. True cowmen and commercial farmers: Exploring vets' and dairy farmers' contrasting views of 'good farming'in relation to biosecurity. Sociologia Ruralis, Accepted Author Manuscript. doi:10.1111/soru.12205.

SIMON-GRIFÉ, M., MARTíN-VALLS, G., VILAR, M., GARCÍA-BOCANEGRA, I., MARTíN, M., MATEU, E. \& CASAL, J. 2013. Biosecurity practices in Spanish pig herds: perceptions of farmers and veterinarians of the most important biosecurity measures. Preventive Veterinary Medicine, 110, 223-231.

TOMA, L., LOW, J., AHMADI, B. V., MATTHEWS, L. \& STOTT, A. 2015. An analysis of cattle farmers' perceptions of drivers and barriers to on-farm control of Escherichia coli 0157. Epidemiology \& Infection, 143, 2355-2366.

VAN DEN BROECK, J., CUNNINGHAM, S. A., EECKELS, R. \& HERBST, K. 2005. Data cleaning: detecting, diagnosing, and editing data abnormalities. PLoS Medicine, 2, e267.

WEBB, T.L. \& SHEERAN, P. 2006. Does changing behavioural intentions engender behaviour change? A meta-analysis of experimental evidence. Psychological Bulletin, 132, 249-268. 


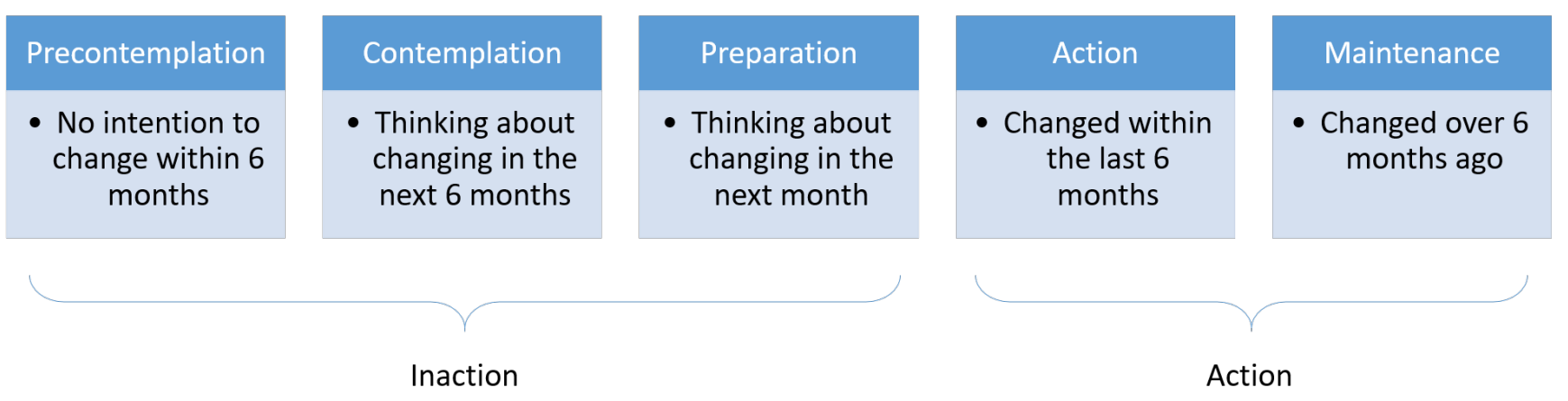

Figure 1: Schematic representation of the stages of change components within the Transtheoretical Model of Behaviour Change 


\section{Attitude}

towards the

behaviour

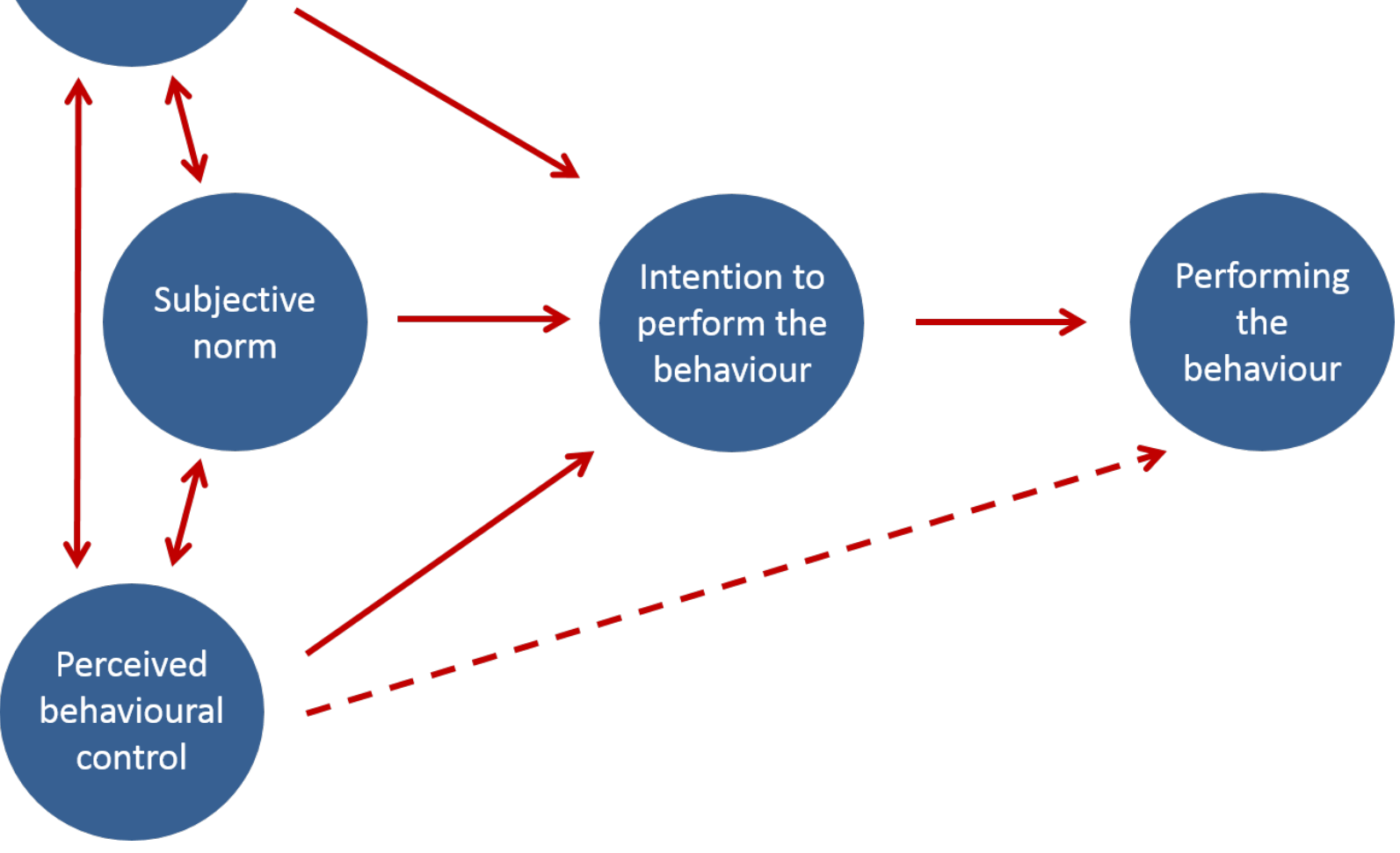

Figure 2: Schematic representing the components of the Theory of Planned Behaviour (as seen in Brennan et al. 2016) 
Disease testing of newly arrived animals

Double fencing around farm

Quarantine of animals arriving at the Only new animal bought onto the farm is

Only buy new stock from known disease Researching the health status of the

Running a closed herd Quarantine of sick animals Minimising contact with neighbours

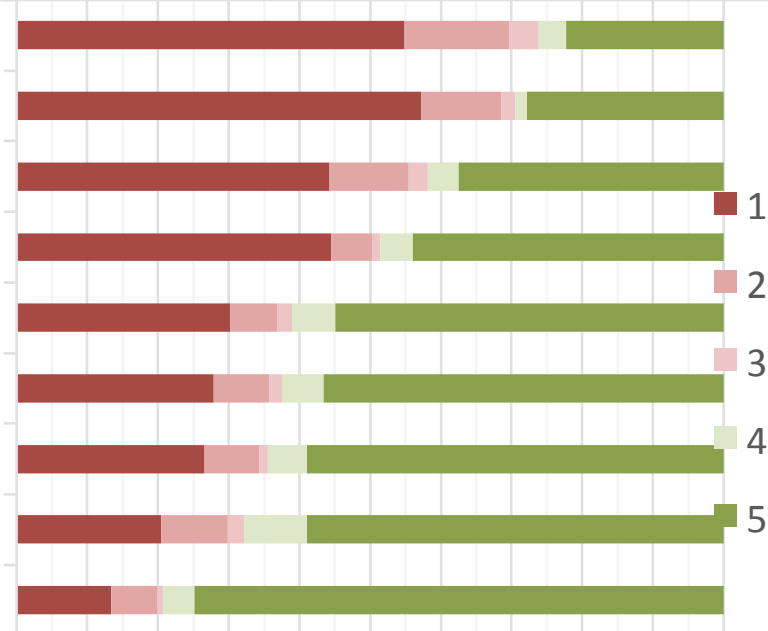

Figure 3: Direct biosecurity measures undertaken as nominated by dairy farmers in the survey. $1=$ I do not do this and have no plans to start doing so; $\mathbf{2}=\mathbf{I}$ do not do this but am thinking of doing so in the near future, $3=I$ do not do this but am preparing to do so in the next month; $4=I$ do this and have done so for up to and including 6 months; 5 = I do this and have done so for over 6 months. For numbers of respondent for each question, please see Appendix 1. 
Provision of bins for dog faeces on footpaths

Restriction of the number of visitors to the

Management of any footpaths through your

Restricting visitor access to livestock

Prevent wildlife accessing housing sheds and

Ensuring visitors clean and disinfect before

Avoid spreading fields with imported slurry

Ensuring general farm cleanliness and hygiene

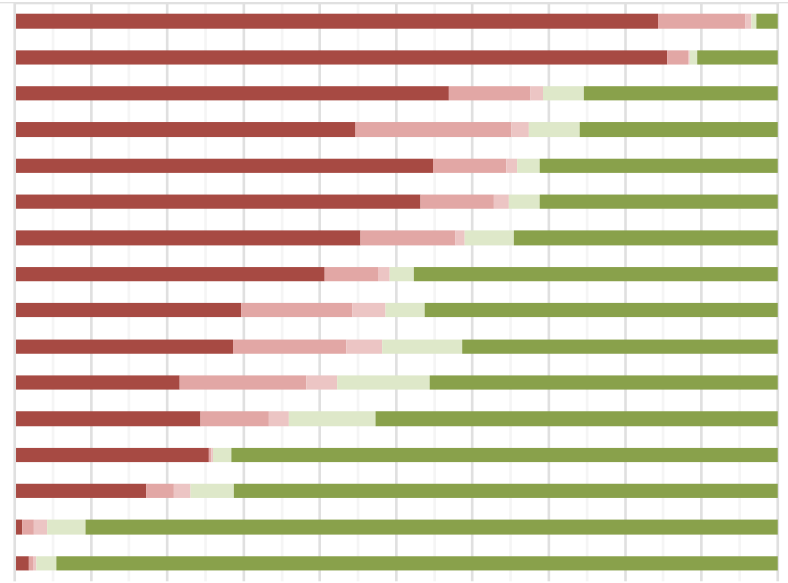

Figure 4: Indirect biosecurity measures undertaken as nominated by dairy farmers in the survey. 1

$=I$ do not do this and have no plans to start doing so; $2=I$ do not do this but am thinking of doing so in the near future, $3=1$ do not do this but am preparing to do so in the next month; $4=I$ do this and have done so for up to and including 6 months; 5 = I do this and have done so for over 6 months. For numbers of respondent for each question, please see Appendix 1. 
Participation in a disease accreditation or control programme

Vaccination used to prevent the occurance of a disease not already circulating on the farm

Breeding for disease resistance

Regular disease testing (except bTB testing)

Vaccination to control the effects of a disease currently circulating on the farm

Review your biosecurity with a vet at least annually

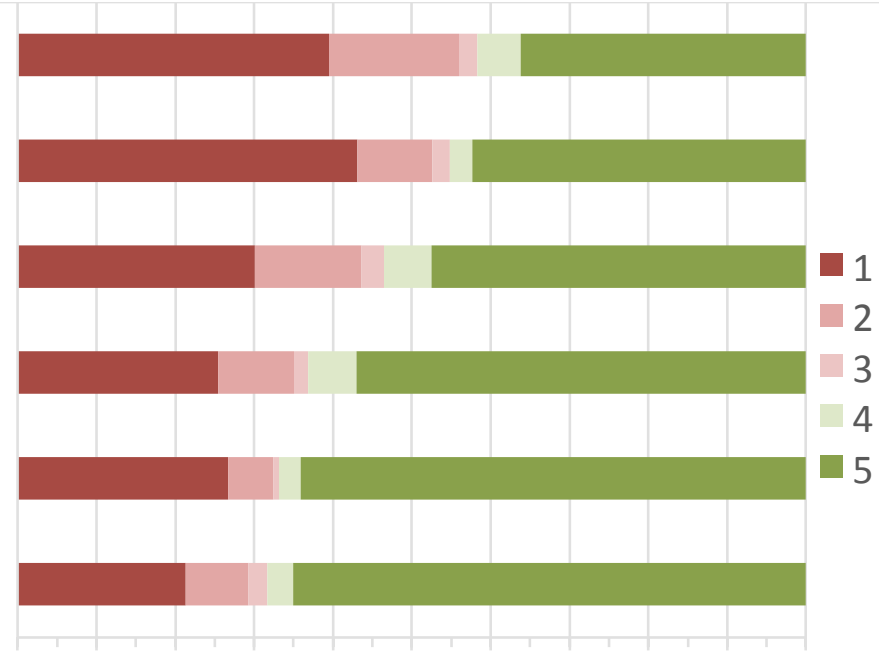

0.010 .020 .030 .040 .050 .060 .070 .080 .090 .0100 .0

Figure 5: Other biosecurity measures undertaken as nominated by dairy farmers in the survey. $1=$ I do not do this and have no plans to start doing so; $2=1$ do not do this but am thinking of doing so in the near future, $3=I$ do not do this but am preparing to do so in the next month; $4=I$ do this and have done so for up to and including 6 months; $5=I$ do this and have done so for over 6 months. For numbers of respondent for each question, please see Appendix 1. 
I think biosecurity measures are worth

Biosecurity needs to be improved in the

Implementing biosecurity measures will

Implementing biosecurity measures will

Implementing biosecurity measures is time

Implementing biosecurity measures will

Implementing biosecurity measures is

I use biosecurity measures every day

I would implement a new biosecurity

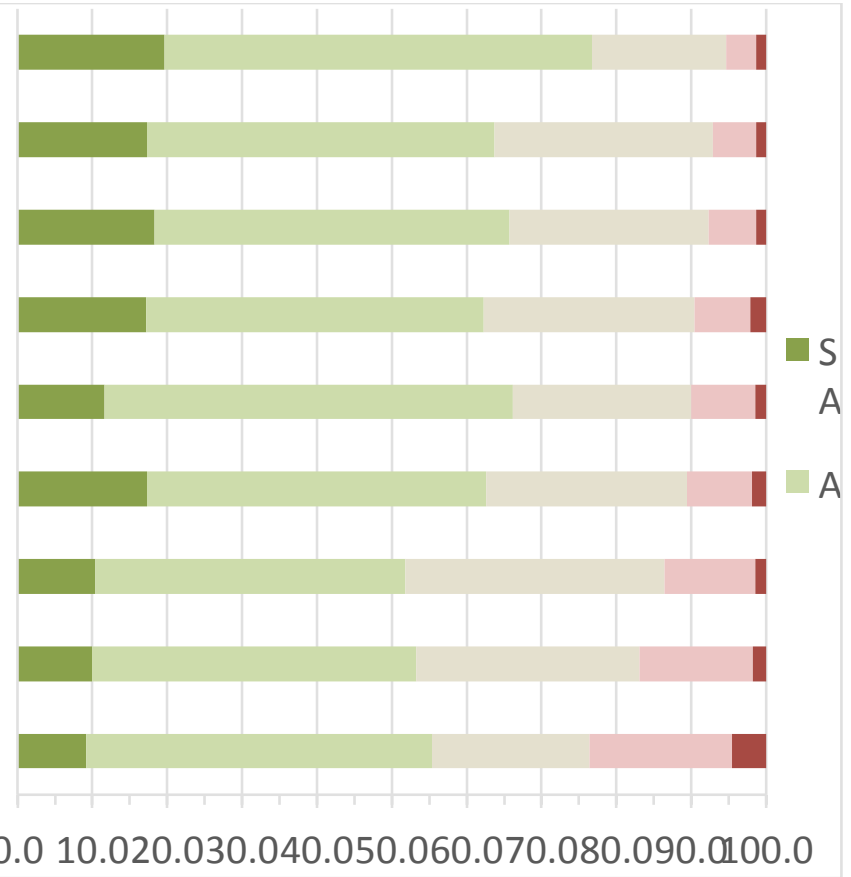

Figure 6: Agreement with statements relating to behavioural beliefs as nominated by dairy

farmers in the survey. $S A=$ Strongly agree; $A=$ Agree; $N=$ Neither agree or disagree; $D=$ Disagree;

SD = Strongly disagree. For numbers of respondent for each question, please see Appendix 2. 
I know the current disease status of my herd

There is evidence biosecurity measures are effective

I am able to control disease once it is on my farm

If I wanted to it would be easy for me to implement a new biosecurity measure

It is inevitable there will be infectious disease on my dairy farm

I am able to prevent disease coming onto my farm

There is no point implementing biosecurity measures on my farm

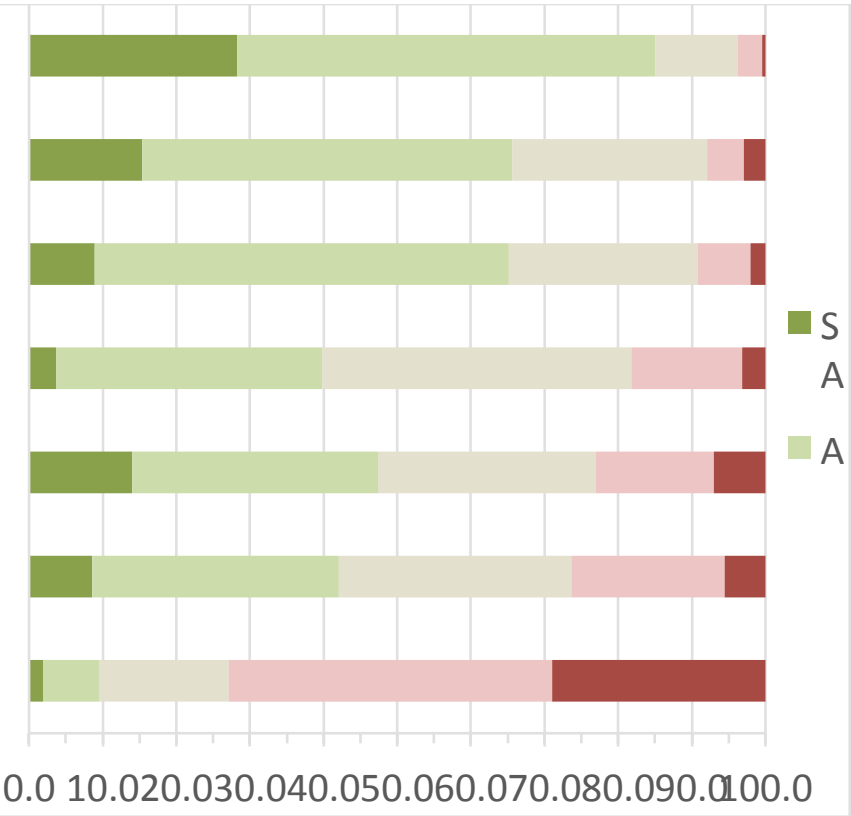

Figure 7: Agreement with statements relating to control beliefs as nominated by dairy farmers in the survey. $\mathrm{SA}=$ Strongly agree; $\mathrm{A}=$ Agree; $\mathrm{N}=$ Neither agree or disagree; $\mathrm{D}=\mathrm{Disagree} ; \mathrm{SD}=$ Strongly disagree. For numbers of respondent for each question, please see Appendix 2. 
Table 1: Percentage agreement with statements relating to the normative beliefs as nominated by dairy farmers in the survey. For numbers of respondent for each question, please see Appendix 2.

\begin{tabular}{|c|c|c|c|c|c|c|c|c|c|}
\hline $\begin{array}{l}\text { 'Person' thinks it is important I implement } \\
\text { biosecurity measures on my farm }\end{array}$ & $\begin{array}{l}\text { My } \\
\text { vet } \\
(\%)\end{array}$ & $\begin{array}{l}\text { Other } \\
\text { vets } \\
(\%)\end{array}$ & $\begin{array}{c}\text { Other } \\
\text { dairy } \\
\text { farmers } \\
(\%)\end{array}$ & $\begin{array}{l}\text { Def } \\
\text { ra } \\
(\%)\end{array}$ & $\begin{array}{c}\text { Farm } \\
\text { consulta } \\
\text { nts (\%) }\end{array}$ & $\begin{array}{l}\text { Farm } \\
\text { technicia } \\
\text { ns (\%) }\end{array}$ & $\begin{array}{l}\text { Sales } \\
\text { representa } \\
\text { tives (\%) }\end{array}$ & $\begin{array}{l}\text { AHDB } \\
\text { Dairy } \\
\text { (\%) }\end{array}$ & $\begin{array}{c}\text { Milk } \\
\text { buyer } \\
(\%)\end{array}$ \\
\hline Strongly agree or Agree & 57.7 & 39.9 & 20.5 & $\begin{array}{c}69 . \\
9\end{array}$ & 41.4 & 40.7 & 28.8 & 62.4 & 72.2 \\
\hline Neither agree or disagree & 30.2 & 43.7 & 51.7 & $\begin{array}{c}22 \\
6\end{array}$ & 43.4 & 42.6 & 50.9 & 29.9 & 21.7 \\
\hline Strongly disagree or Disagree & 12.1 & 16.3 & 27.8 & 7.6 & 15.2 & 16.7 & 20.3 & 7.7 & 6.1 \\
\hline $\begin{array}{l}\text { The opinion of 'Person' is important to me in } \\
\text { relation to implementation of biosecurity } \\
\text { measures on my farm }\end{array}$ & $\begin{array}{l}\text { My } \\
\text { vet } \\
(\%)\end{array}$ & $\begin{array}{l}\text { Other } \\
\text { vets } \\
\text { (\%) }\end{array}$ & $\begin{array}{l}\text { Other } \\
\text { dairy } \\
\text { farmers } \\
\text { (\%) }\end{array}$ & $\begin{array}{l}\text { Def } \\
\text { ra } \\
(\%)\end{array}$ & $\begin{array}{l}\text { Farm } \\
\text { consulta } \\
\text { nts (\%) }\end{array}$ & $\begin{array}{l}\text { Farm } \\
\text { technicia } \\
\text { ns (\%) }\end{array}$ & $\begin{array}{l}\text { Sales } \\
\text { representa } \\
\text { tives (\%) }\end{array}$ & $\begin{array}{l}\text { AHDB } \\
\text { Dairy } \\
(\%)\end{array}$ & $\begin{array}{l}\text { Milk } \\
\text { buyer } \\
(\%)\end{array}$ \\
\hline Strongly agree or Agree & 82.1 & 38.7 & 36.4 & $\begin{array}{c}51 . \\
7\end{array}$ & 32.3 & 37.1 & 16.7 & 39.9 & 83.2 \\
\hline Neither agree or disagree & 13.8 & 42.8 & 43.6 & $\begin{array}{c}34 . \\
7\end{array}$ & 45.9 & 44.3 & 47.1 & 41.0 & 12.9 \\
\hline Strongly disagree or Disagree & 4.1 & 18.5 & 20.0 & $\begin{array}{c}13 . \\
6\end{array}$ & 21.8 & 18.6 & 36.3 & 19.2 & 3.9 \\
\hline
\end{tabular}


Table 2: Multivariable logistic regression with outcome variable relating to methods focused on the prevention of direct contact between animals

\begin{tabular}{|l|c|c|c|c|}
\hline \multicolumn{1}{|c|}{ Variable } & P-value & \multicolumn{2}{c|}{ Odds } & \multicolumn{2}{c|}{$95 \% \mathrm{Cl}$} \\
\cline { 3 - 5 } & & & Lotio & Upper \\
\hline $\begin{array}{l}\text { I know the current disease } \\
\text { status of my herd }\end{array}$ & 0.002 & 0.69 & 0.55 & 0.87 \\
\hline $\begin{array}{l}\text { There is a point to } \\
\text { implementing biosecurity } \\
\text { measures on my farm }\end{array}$ & 0.003 & 0.76 & 0.63 & 0.91 \\
\hline $\begin{array}{l}\text { Mean Subjective Norm } \\
\text { El }\end{array}$ & 0.001 & 0.58 & 0.42 & 0.81 \\
\hline $\begin{array}{l}\text { Explained variance: } 9 \% \text { (Cox \& Snell R Square)-12\% (Nagelkerke R Square) } \\
\text { Hosmer and Lemeshow model fit: } X^{2}=14.00 ; p=0.08\end{array}$ & & & \\
\hline Age of farmer & & & & \\
\hline Size of milking herd & 0.03 & 1.00 & 1.00 & 1.00 \\
\hline $\begin{array}{l}\text { Number of emergency vet } \\
\text { visits in past 3 months }\end{array}$ & 0.004 & 0.89 & 0.82 & 0.96 \\
\hline
\end{tabular}


Table 3: Multivariable logistic regression with outcome variable relating to methods focused on the prevention of indirect contacts

\begin{tabular}{|c|c|c|c|c|}
\hline \multirow[t]{2}{*}{ Variable } & \multirow[t]{2}{*}{ P-value } & \multirow{2}{*}{$\begin{array}{l}\text { Odds } \\
\text { ratio }\end{array}$} & \multicolumn{2}{|c|}{$95 \% \mathrm{Cl}$} \\
\hline & & & Lower & Upper \\
\hline $\begin{array}{l}\text { I know the current disease } \\
\text { status of my herd }\end{array}$ & 0.06 & 0.80 & 0.64 & 1.01 \\
\hline $\begin{array}{l}\text { There is a point to } \\
\text { implementing biosecurity } \\
\text { measures on my farm }\end{array}$ & 0.001 & 0.70 & 0.57 & 0.86 \\
\hline $\begin{array}{l}\text { Infectious disease is not } \\
\text { inevitable on my farm }\end{array}$ & 0.004 & 0.80 & 0.69 & 0.93 \\
\hline Mean Behavioural Belief & 0.001 & 0.55 & 0.40 & 0.80 \\
\hline $\begin{array}{l}\text { Number of emergency vet } \\
\text { visits in the past } 3 \text { months }\end{array}$ & 0.04 & 0.92 & 0.86 & 1.00 \\
\hline
\end{tabular}


Table 4: Multivariable logistic regression with outcome variable relating to methods focused on the prevention of other types of contacts

\begin{tabular}{|c|c|c|c|c|}
\hline \multirow[t]{2}{*}{ Variable } & \multirow[t]{2}{*}{ P-value } & \multirow{2}{*}{$\begin{array}{l}\text { Odds } \\
\text { ratio }\end{array}$} & \multicolumn{2}{|c|}{$95 \% \mathrm{Cl}$} \\
\hline & & & Lower & Upper \\
\hline $\begin{array}{l}\text { I know the current disease } \\
\text { status of my herd }\end{array}$ & 0.001 & 0.69 & 0.55 & 0.86 \\
\hline $\begin{array}{l}\text { There is a point to } \\
\text { implementing biosecurity } \\
\text { measures on my farm }\end{array}$ & 0.003 & 0.77 & 0.64 & 0.91 \\
\hline Mean Subjective Norm & 0.003 & 0.61 & 0.44 & 0.84 \\
\hline Size of the milking herd & 0.02 & 1.00 & 1.00 & 1.00 \\
\hline $\begin{array}{l}\text { Number of preplanned vet } \\
\text { visits in the past } 3 \text { months }\end{array}$ & 0.004 & 1.07 & 1.02 & 1.13 \\
\hline
\end{tabular}


Appendix 1:

\begin{tabular}{|l|l|l|}
\hline Biosecurity measures - Prevention of direct contacts & $\begin{array}{l}\text { Number of } \\
\text { respondents }\end{array}$ & Missing \\
\hline Running a closed herd & 743 & 14 \\
\hline Only new animal bought onto the farm is the occasional bull & 703 & 54 \\
\hline Only buy new stock from known disease status herds & 686 & 71 \\
\hline Researching the health status of the stock prior to purchase & 671 & 86 \\
\hline Quarantine of animals arriving at the farm & 662 & 95 \\
\hline Quarantine of sick animals & 710 & 47 \\
\hline Disease testing of newly arrived animals (apart from bTB testing) & 654 & 103 \\
\hline Double fencing around farm & 732 & 25 \\
\hline Minimising contact with neighbours animals & 734 & 23 \\
\hline
\end{tabular}

\begin{tabular}{|l|l|l|}
\hline Biosecurity measures - Prevention of indirect contacts & $\begin{array}{l}\text { Number of } \\
\text { respondents }\end{array}$ & Missing \\
\hline Restricting visitor access to livestock & 748 & 9 \\
\hline Restriction of the number of visitors to the farm & 744 & 13 \\
\hline $\begin{array}{l}\text { Checking the cleanliness and disinfection of visitors' vehicles } \\
\text { and equipment }\end{array}$ & 743 & 14 \\
\hline Ensuring vehicles park away from livestock areas & 745 & 12 \\
\hline $\begin{array}{l}\text { Ensuring visitors clean and disinfect before entering } \\
\text { livestock areas }\end{array}$ & 748 & 9 \\
\hline Ensure visitors clean and disinfect after their visit & 745 & 12 \\
\hline Avoid sharing equipment with other farmers & 731 & 26 \\
\hline Avoid grazing pastures recently spread with slurry & 734 & 23 \\
\hline Avoid spreading fields with imported slurry & 731 \\
\hline Regular vermin control & 74 \\
\hline Prevent wildlife accessing housing sheds and food supplies & & \\
\hline
\end{tabular}




\begin{tabular}{|l|l|l|}
\hline Cows are housed all year round & 731 & 26 \\
\hline Ensuring general farm cleanliness and hygiene & 744 & 13 \\
\hline Management of any footpaths through your farm & 545 & 212 \\
\hline $\begin{array}{l}\text { Provision of bins for dog faeces on footpaths through your } \\
\text { farm }\end{array}$ & 541 & 216 \\
\hline $\begin{array}{l}\text { Prevent cattle having access to waterways common to } \\
\text { multiple farms }\end{array}$ & 414 & 343 \\
\hline
\end{tabular}

\begin{tabular}{|l|l|l|}
\hline Biosecurity measures - Prevention of other contacts & $\begin{array}{l}\text { Number of } \\
\text { respondents }\end{array}$ & Missing \\
\hline $\begin{array}{l}\text { Vaccination used to prevent the occurrence of a disease not } \\
\text { already circulating on the farm }\end{array}$ & 735 & 22 \\
\hline $\begin{array}{l}\text { Vaccination to control the effects of a disease currently } \\
\text { circulating on the farm }\end{array}$ & 729 & 28 \\
\hline Regular disease testing (except bTB testing) & 736 & 21 \\
\hline Participation in a disease accreditation or control programme & 729 & 28 \\
\hline Review your biosecurity with a vet at least annually & 742 & 15 \\
\hline Breeding for disease resistance & 734 & 23 \\
\hline
\end{tabular}


Appendix 2:

\begin{tabular}{|l|l|l|}
\hline Questions relating to behavioural beliefs & $\begin{array}{l}\text { Number of } \\
\text { respondents }\end{array}$ & Missing \\
\hline I think biosecurity measures are worth implementing & 745 & 12 \\
\hline $\begin{array}{l}\text { Implementing biosecurity measures will improve the } \\
\text { health of my cattle }\end{array}$ & 745 & 12 \\
\hline $\begin{array}{l}\text { Implementing biosecurity measures will improve the } \\
\text { welfare of my cattle }\end{array}$ & 746 & 11 \\
\hline $\begin{array}{l}\text { Implementing biosecurity measures will improve the } \\
\text { productivity of my cattle }\end{array}$ & 745 & 12 \\
\hline $\begin{array}{l}\text { I would implement a new biosecurity measure only if I had } \\
\text { a disease problem }\end{array}$ & 741 & 16 \\
\hline Implementing biosecurity measures is time consuming & 740 & 17 \\
\hline Implementing biosecurity measures is costly & 741 & 16 \\
\hline $\begin{array}{l}\text { Biosecurity needs to be improved in the dairy industry as a } \\
\text { whole }\end{array}$ & 739 & 18 \\
\hline \begin{tabular}{l} 
I use biosecurity measures every day \\
\hline
\end{tabular} & 743 & 14 \\
\hline
\end{tabular}

\begin{tabular}{|l|l|l|}
\hline Questions relating to control beliefs & $\begin{array}{l}\text { Number of } \\
\text { respondents }\end{array}$ & Missing \\
\hline $\begin{array}{l}\text { It is inevitable there will be infectious disease on my dairy } \\
\text { farm }\end{array}$ & 740 & 17 \\
\hline I am able to prevent disease coming onto my farm & 735 & 22 \\
\hline I am able to control disease once it is on my farm & 740 & 17 \\
\hline I know the current disease status of my herd & 741 & 16 \\
\hline $\begin{array}{l}\text { There is no point implementing biosecurity measures on } \\
\text { my farm }\end{array}$ & 742 & 15 \\
\hline $\begin{array}{l}\text { There is evidence biosecurity measures are effective } \\
\text { If I wanted to it would be easy for me to implement a new } \\
\text { biosecurity measure }\end{array}$ & 739 & 13 \\
\hline
\end{tabular}




\begin{tabular}{|c|c|c|}
\hline Questions relating to normative beliefs & $\begin{array}{l}\text { Number of } \\
\text { respondents }\end{array}$ & Missing \\
\hline $\begin{array}{l}\text { I feel pressure from people around me to implement biosecurity } \\
\text { measures }\end{array}$ & 742 & 15 \\
\hline $\begin{array}{l}\text { My vet thinks it is important that I implement biosecurity measures on } \\
\text { my farm }\end{array}$ & 744 & 13 \\
\hline $\begin{array}{l}\text { Other vets think it is important that I implement biosecurity measures on } \\
\text { my farm }\end{array}$ & 734 & 23 \\
\hline $\begin{array}{l}\text { Other dairy farmers think it is important that I implement biosecurity } \\
\text { measures on my farm }\end{array}$ & 735 & 22 \\
\hline $\begin{array}{l}\text { Defra thinks it is important that I implement biosecurity measures on my } \\
\text { farm }\end{array}$ & 740 & 17 \\
\hline $\begin{array}{l}\text { Farm consultants (e.g. nutritionists) think it is important that I implement } \\
\text { biosecurity measures on my farm }\end{array}$ & 732 & 25 \\
\hline $\begin{array}{l}\text { Farm technicians think it is important that I implement biosecurity } \\
\text { measures on my farm }\end{array}$ & 732 & 25 \\
\hline $\begin{array}{l}\text { Sales representatives (e.g. pharmaceutical) think it is important that I } \\
\text { implement biosecurity measures on my farm }\end{array}$ & 733 & 24 \\
\hline $\begin{array}{l}\text { AHDB Dairy (formerly DairyCo) think it is important that I implement } \\
\text { biosecurity measures on my farm }\end{array}$ & 726 & 31 \\
\hline $\begin{array}{l}\text { My milk buyer thinks it is important that I implement biosecurity } \\
\text { measures on my farm }\end{array}$ & 737 & 20 \\
\hline $\begin{array}{l}\text { The opinion of my vet is important to me in relation to the } \\
\text { implementation of biosecurity measures on my farm }\end{array}$ & 738 & 19 \\
\hline $\begin{array}{l}\text { The opinion of other vets is important to me in relation to the } \\
\text { implementation of biosecurity measures on my farm }\end{array}$ & 741 & 16 \\
\hline $\begin{array}{l}\text { The opinion of other dairy farmers is important to me in relation to the } \\
\text { implementation of biosecurity measures on my farm }\end{array}$ & 739 & 18 \\
\hline $\begin{array}{l}\text { The opinion of farm consultants is important to me in relation to the } \\
\text { implementation of biosecurity measures on my farm }\end{array}$ & 737 & 20 \\
\hline $\begin{array}{l}\text { The opinion of farm technicians is important to me in relation to the } \\
\text { implementation of biosecurity measures on my farm }\end{array}$ & 733 & 24 \\
\hline The opinion of sales representatives is important to me in relation to the & 731 & 26 \\
\hline
\end{tabular}




\begin{tabular}{|l|l|l|}
\hline implementation of biosecurity measures on my farm & & \\
\hline $\begin{array}{l}\text { The opinion of Defra is important to me in relation to the } \\
\text { implementation of biosecurity measures on my farm }\end{array}$ & 735 & 22 \\
\hline $\begin{array}{l}\text { The opinion of AHDB (formerly DairyCo) is important to me in relation to } \\
\text { the implementation of biosecurity measures on my farm }\end{array}$ & 730 & 27 \\
\hline $\begin{array}{l}\text { The opinion of my milk buyer is important to me in relation to the } \\
\text { implementation of biosecurity measures on my farm }\end{array}$ & 737 & 20 \\
\hline
\end{tabular}


Appendix 3: Result of the univariable logistic regression analyses with outcome variable relating to methods focused on the prevention of direct, indirect and other contact between animals

\begin{tabular}{|c|c|c|c|}
\hline Variable & Direct model & Indirect model & Other model \\
\hline & To be included? & To be included? & To be included? \\
\hline Mean Behavioural Belief & $\mathrm{Y}$ & $\mathrm{Y}$ & $\mathrm{Y}$ \\
\hline Mean Normative Belief & $\mathrm{Y}$ & $\mathrm{Y}$ & $\mathrm{Y}$ \\
\hline Infectious disease is not inevitable on my farm & $\mathrm{N}$ & Y & $\mathrm{N}$ \\
\hline $\begin{array}{l}\text { I am able to prevent disease coming onto my } \\
\text { farm }\end{array}$ & $\mathrm{Y}$ & Y & $\mathrm{N}$ \\
\hline $\begin{array}{l}\text { I am able to control disease once it is on my } \\
\text { farm }\end{array}$ & $\mathrm{N}$ & $\mathrm{Y}$ & $\mathrm{Y}$ \\
\hline I know the current disease status of my herd & Y & Y & Y \\
\hline $\begin{array}{l}\text { There is a point to implementing biosecurity } \\
\text { measures on my farm }\end{array}$ & $\mathrm{Y}$ & $\mathrm{Y}$ & $\mathrm{Y}$ \\
\hline $\begin{array}{l}\text { There is evidence that biosecurity measures are } \\
\text { effective }\end{array}$ & $\mathrm{Y}$ & $\mathrm{Y}$ & $\mathrm{Y}$ \\
\hline $\begin{array}{l}\text { If I wanted to it would be easy for me to } \\
\text { implement a new biosecurity measure }\end{array}$ & $\mathrm{N}$ & Y & $\mathrm{N}$ \\
\hline Age of farmer & $\mathrm{Y}$ & $\mathrm{N}$ & $\mathrm{Y}$ \\
\hline Size of milking herd & $\mathrm{Y}$ & $\mathrm{N}$ & $\mathrm{Y}$ \\
\hline Assurance, health or disease scheme (Yes or No) & $\mathrm{N}$ & $\mathrm{N}$ & $\mathrm{N}$ \\
\hline $\begin{array}{l}\text { Number of pre-planned vet visits in past } 3 \\
\text { months }\end{array}$ & $\mathrm{N}$ & $\mathrm{N}$ & Y \\
\hline $\begin{array}{l}\text { Number of emergency vet visits in past } 3 \\
\text { months }\end{array}$ & $\mathrm{Y}$ & Y & $\mathrm{N}$ \\
\hline
\end{tabular}


Appendix 4: Univariable logistic regression analyses with outcome variable relating to methods focused on the prevention of direct contact between animals.

\begin{tabular}{|c|c|c|c|c|c|c|c|c|}
\hline Variable & $\beta$ & SE & Wald & df & & Odds & $95 \% \mathrm{Cl}$ & \\
\hline & & & & & & & Lower & Upper \\
\hline Mean Behavioural Belief & -0.458 & 0.135 & 11.484 & 1 & 0.001 & 0.633 & 0.485 & 0.824 \\
\hline Mean Normative Belief & -0.598 & 0.142 & 17.843 & 1 & 0.000 & 0.550 & 0.417 & 0.726 \\
\hline $\begin{array}{l}\text { Infectious disease is not } \\
\text { inevitable on my farm }\end{array}$ & -0.028 & 0.067 & 0.173 & 1 & 0.678 & 0.973 & 0.853 & 1.109 \\
\hline $\begin{array}{l}\text { I am able to prevent disease } \\
\text { coming onto my farm }\end{array}$ & -0.121 & 0.072 & 2.813 & 1 & 0.094 & 0.886 & 0.769 & 1.021 \\
\hline $\begin{array}{l}\text { I am able to control disease once } \\
\text { it is on } \mathrm{my} \text { farm }\end{array}$ & -0.080 & 0.091 & 0.777 & 1 & 0.378 & 0.923 & 0.772 & 1.103 \\
\hline $\begin{array}{l}\text { I know the current disease status } \\
\text { of my herd }\end{array}$ & -0.389 & 0.102 & 14.470 & 1 & 0.000 & 0.678 & 0.554 & 0.828 \\
\hline $\begin{array}{l}\text { There is a point to implementing } \\
\text { biosecurity measures on my farm }\end{array}$ & -0.345 & 0.079 & 18.979 & 1 & 0.000 & 0.708 & 0.607 & 0.827 \\
\hline $\begin{array}{l}\text { There is evidence that } \\
\text { biosecurity measures are } \\
\text { effective }\end{array}$ & -0.167 & 0.083 & 3.995 & 1 & 0.046 & 0.846 & 0.719 & 0.997 \\
\hline $\begin{array}{l}\text { If I wanted to it would be easy } \\
\text { for me to implement a new } \\
\text { biosecurity measure }\end{array}$ & -0.032 & 0.087 & 0.137 & 1 & 0.711 & 0.968 & 0.817 & 1.148 \\
\hline Age of farmer & 0.013 & 0.006 & 4.597 & 1 & 0.032 & 1.013 & 1.001 & 1.025 \\
\hline Size of milking herd & 0.001 & 0.001 & 3.547 & 1 & 0.060 & 1.001 & 1.000 & 1.002 \\
\hline $\begin{array}{l}\text { Assurance, health or disease } \\
\text { scheme (Yes or No) }\end{array}$ & -0.100 & 0.523 & 0.037 & 1 & 0.848 & 0.905 & 0.325 & 2.521 \\
\hline $\begin{array}{l}\text { Number of pre-planned vet visits } \\
\text { in past } 3 \text { months }\end{array}$ & 0.012 & 0.017 & 0.491 & 1 & 0.483 & 1.012 & 0.979 & 1.047 \\
\hline $\begin{array}{l}\text { Number of emergency vet visits } \\
\text { in past } 3 \text { months }\end{array}$ & -0.062 & 0.034 & 3.422 & 1 & 0.064 & 0.940 & 0.880 & 1.004 \\
\hline
\end{tabular}

$\beta=$ Beta; $\mathrm{SE}=$ Standard error $; \mathrm{df}=$ Degrees of freedom; $\mathrm{Cl}=$ Confidence interval 
Appendix 5: Univariable logistic regression analyses with outcome variable relating to methods focused on the prevention of indirect contact between animals.

\begin{tabular}{|c|c|c|c|c|c|c|c|c|}
\hline \multirow[t]{2}{*}{ Variable } & \multirow[t]{2}{*}{$\beta$} & \multirow[t]{2}{*}{ SE } & \multirow[t]{2}{*}{ Wald } & \multirow[t]{2}{*}{ df } & \multirow{2}{*}{$\begin{array}{l}\text { P- } \\
\text { value }\end{array}$} & \multirow{2}{*}{$\begin{array}{l}\text { Odds } \\
\text { ratio }\end{array}$} & \multicolumn{2}{|l|}{$95 \% \mathrm{Cl}$} \\
\hline & & & & & & & Lower & Upper \\
\hline Mean Behavioural Belief & -0.919 & 0.144 & 40.660 & 1 & 0.000 & 0.399 & 0.301 & 0.529 \\
\hline Mean Normative Belief & -0.562 & 0.140 & 16.081 & 1 & 0.000 & 0.570 & 0.433 & 0.750 \\
\hline $\begin{array}{l}\text { Infectious disease is not inevitable } \\
\text { on my farm }\end{array}$ & -0.226 & 0.067 & 11.230 & 1 & 0.001 & 0.798 & 0.699 & 0.910 \\
\hline $\begin{array}{l}\text { I am able to prevent disease coming } \\
\text { onto my farm }\end{array}$ & -0.182 & 0.072 & 6.392 & 1 & 0.011 & 0.834 & 0.724 & 0.960 \\
\hline $\begin{array}{l}\text { I am able to control disease once it } \\
\text { is on my farm }\end{array}$ & -0.260 & 0.091 & 8.109 & 1 & 0.004 & 0.771 & 0.645 & 0.922 \\
\hline $\begin{array}{l}\text { I know the current disease status of } \\
\text { my herd }\end{array}$ & -0.295 & 0.101 & 8.592 & 1 & 0.003 & 0.744 & 0.611 & 0.907 \\
\hline $\begin{array}{l}\text { There is a point to implementing } \\
\text { biosecurity measures on my farm }\end{array}$ & -0.562 & 0.084 & 44.587 & 1 & 0.000 & 0.570 & 0.483 & 0.672 \\
\hline $\begin{array}{l}\text { There is evidence that biosecurity } \\
\text { measures are effective }\end{array}$ & -0.326 & 0.085 & 14.601 & 1 & 0.000 & 0.722 & 0.610 & 0.853 \\
\hline $\begin{array}{l}\text { If I wanted to it would be easy for } \\
\text { me to implement a new biosecurity } \\
\text { measure }\end{array}$ & -0.204 & 0.087 & 5.545 & 1 & 0.019 & 0.815 & 0.688 & 0.966 \\
\hline Age of farmer & 0.005 & 0.006 & 0.712 & 1 & 0.399 & 1.005 & 0.993 & 1.017 \\
\hline Size of milking herd & 0.000 & 0.000 & 0.003 & 1 & 0.959 & 1.000 & 0.999 & 1.001 \\
\hline $\begin{array}{l}\text { Assurance, health or disease } \\
\text { scheme (Yes or No) }\end{array}$ & -0.477 & 0.532 & 0.803 & 1 & 0.370 & 0.621 & 0.219 & 1.762 \\
\hline $\begin{array}{l}\text { Number of pre-planned vet visits in } \\
\text { past } 3 \text { months }\end{array}$ & -0.019 & 0.017 & 1.226 & 1 & 0.268 & 0.981 & 0.949 & 1.015 \\
\hline $\begin{array}{l}\text { Number of emergency vet visits in } \\
\text { past } 3 \text { months }\end{array}$ & -0.099 & 0.036 & 7.656 & 1 & 0.006 & 0.906 & 0.845 & 0.972 \\
\hline
\end{tabular}

$\beta=$ Beta; $\mathrm{SE}=$ Standard error $; \mathrm{df}=$ Degrees of freedom; $\mathrm{Cl}=$ Confidence interval 
Appendix 6: Univariable logistic regression analyses with outcome variable relating to methods focused on the prevention of other contact between animals.

\begin{tabular}{|c|c|c|c|c|c|c|c|c|}
\hline Variable & $\beta$ & SE & Wald & df & & Odds & $95 \% \mathrm{Cl}$ & \\
\hline & & & & & & & Lower & Upper \\
\hline Mean Behavioural Belief & -0.684 & 0.141 & 23.621 & 1 & 0.000 & 0.505 & 0.383 & 0.665 \\
\hline Mean Normative Belief & -0.697 & 0.145 & 23.052 & 1 & 0.000 & 0.498 & 0.375 & 0.662 \\
\hline $\begin{array}{l}\text { Infectious disease is not } \\
\text { inevitable on my farm }\end{array}$ & 0.052 & 0.067 & 0.604 & 1 & 0.437 & 1.054 & 0.924 & 1.202 \\
\hline $\begin{array}{l}\text { I am able to prevent disease } \\
\text { coming onto my farm }\end{array}$ & -0.067 & 0.073 & 0.854 & 1 & 0.355 & 0.935 & 0.811 & 1.078 \\
\hline $\begin{array}{l}\text { I am able to control disease } \\
\text { once it is on my farm }\end{array}$ & -0.196 & 0.092 & 4.559 & 1 & 0.033 & 0.822 & 0.686 & 0.984 \\
\hline $\begin{array}{l}\text { I know the current disease } \\
\text { status of my herd }\end{array}$ & -0.521 & 0.106 & 23.928 & 1 & 0.000 & 0.594 & 0.482 & 0.732 \\
\hline $\begin{array}{l}\text { There is a point to } \\
\text { implementing biosecurity } \\
\text { measures on my farm }\end{array}$ & -0.418 & 0.081 & 26.855 & 1 & 0.000 & 0.658 & 0.562 & 0.771 \\
\hline $\begin{array}{l}\text { There is evidence that } \\
\text { biosecurity measures are } \\
\text { effective }\end{array}$ & -0.296 & 0.085 & 12.083 & 1 & 0.001 & 0.743 & 0.629 & 0.879 \\
\hline $\begin{array}{l}\text { If I wanted to it would be } \\
\text { easy for me to implement a } \\
\text { new biosecurity measure }\end{array}$ & 0.001 & 0.087 & 0.000 & 1 & 0.992 & 1.001 & 0.844 & 1.187 \\
\hline Age of farmer & -0.008 & 0.006 & 1.491 & 1 & 0.222 & 0.992 & 0.981 & 1.005 \\
\hline Size of milking herd & 0.003 & 0.001 & 13.315 & 1 & 0.000 & 1.003 & 1.001 & 1.004 \\
\hline $\begin{array}{l}\text { Assurance, health or disease } \\
\text { scheme (Yes or No) }\end{array}$ & -0.059 & 0.545 & 0.012 & 1 & 0.914 & 0.943 & 0.324 & 2.746 \\
\hline $\begin{array}{l}\text { Number of pre-planned vet } \\
\text { visits in past } 3 \text { months }\end{array}$ & 0.116 & 0.023 & 25.618 & 1 & 0.000 & 1.123 & 1.074 & 1.175 \\
\hline $\begin{array}{l}\text { Number of emergency vet } \\
\text { visits in past } 3 \text { months }\end{array}$ & 0.033 & 0.034 & 0.948 & 1 & 0.330 & 1.034 & 0.967 & 1.106 \\
\hline
\end{tabular}

$\beta=$ Beta; $\mathrm{SE}=$ Standard error $; \mathrm{df}=$ Degrees of freedom; $\mathrm{Cl}=$ Confidence interval 